\title{
Recent Advances in Extracellular Vesicles as Drug Delivery Systems and Their Potential in Precision Medicine
}

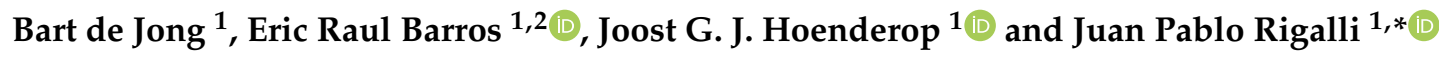 \\ 1 Department of Physiology, Radboud Institute for Molecular Life Sciences, \\ Radboud University Medical Center, 6500HB Nijmegen, The Netherlands; \\ Bart.deJong@radboudumc.nl (B.d.J.); eabarros@uc.cl (E.R.B.); joost.hoenderop@radboudumc.nl (J.G.J.H.) \\ 2 Department of Endocrinology, School of Medicine, Pontificia Universidad Católica de Chile, \\ Santiago 8320000, Chile \\ * Correspondence: juanpablo.rigalli@radboudumc.nl
}

Received: 30 September 2020; Accepted: 20 October 2020; Published: 22 October 2020

\begin{abstract}
Extracellular vesicles (EVs) are membrane-bilayered nanoparticles released by most cell types. Recently, an enormous number of studies have been published on the potential of EVs as carriers of therapeutic agents. In contrast to systems such as liposomes, EVs exhibit less immunogenicity and higher engineering potential. Here, we review the most relevant publications addressing the potential and use of EVs as a drug delivery system (DDS). The information is divided based on the key steps for designing an EV-mediated delivery strategy. We discuss possible sources and isolation methods of EVs. We address the administration routes that have been tested in vivo and the tissue distribution observed. We describe the current knowledge on EV clearance, a significant challenge towards enhancing bioavailability. Also, EV-engineering approaches are described as alternatives to improve tissue and cell-specificity. Finally, a summary of the ongoing clinical trials is performed. Although the application of EVs in the clinical practice is still at an early stage, a high number of studies in animals support their potential as DDS. Thus, better treatment options could be designed to precisely increase target specificity and therapeutic efficacy while reducing off-target effects and toxicity according to the individual requirements of each patient.
\end{abstract}

Keywords: exosomes; extracellular vesicles; drug delivery; nanoparticles; precision medicine

\section{Introduction}

\subsection{The Need for Advanced Drug Delivery Systems}

The therapeutic efficacy of any pharmacological treatment depends on achieving an optimal drug concentration at the site of action. This is strongly influenced by the absorption, distribution, metabolism and excretion of therapeutic agents. Moreover, these processes do not exert a constant and predictable influence on the drug concentration at the site of action, but, on the contrary, are subject to a dynamic regulation. Exposure to other xenobiotics, changes in the diet and metabolism, and disease states may affect, for instance, the expression and activity of drug transporters and metabolizing enzymes and, ultimately, influence the concentration of a drug at its active site and thus, its therapeutic efficacy [1,2]. In this regard, selectively surpassing the physiological mechanisms responsible for limiting drug absorption, and more importantly, those mediating drug clearance, may increase drug bioavailability. Furthermore, the fine-tuning of drug delivery to particular tissues and to particular cells, constitutes a strategy not only to enhance the availability of a drug at the required site but also to reduce the chemical burden to other tissues. 
EV-based therapies could offer a significant advantage in the delivery of drugs to specific targets. This would contribute to the already on-going shift from the old paradigm of one treatment for all the patients with the same disease to a new paradigm where each patient receives a tailored therapy based on individualised parameters. This potential is reflected in the immense expansion of knowledge within this field in the past years, with high impact papers being continuously released and showing the diverse possibilities offered by EVs in different animal models. In this article, we review the latest (i.e., published in the last 5 years) and most sound studies on this novel application of EVs as a drug delivery system (DDS). Reviewed articles comprise publications describing the use of EVs as drug carriers and studies where EVs represented the therapeutic agent, as important information on the biodistribution and tissue specificity can also be gained from the latter studies. Information is presented based on the logic work-flow followed towards designing an EV-based therapy. First, the techniques for isolation and purification of EVs will be presented. Afterwards, different strategies to load EVs with therapeutic agents will be discussed. Following, we will describe possible administration routes for EV-based therapy and how tissue specificity and bioavailability can be enhanced. These different phases of an EV-based therapy are summarized in Figure 1.

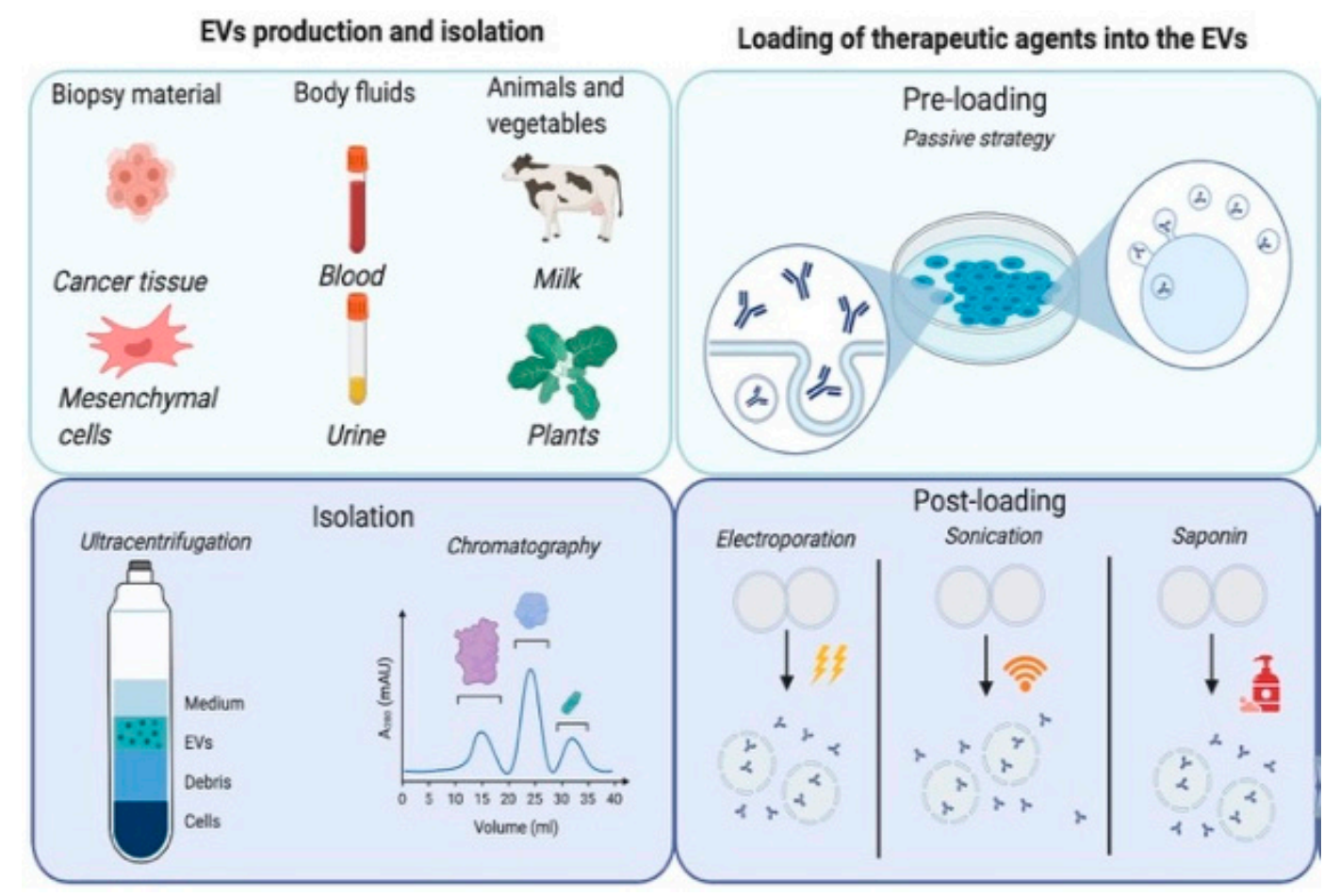

Figure 1. Cont. 
Engineering the EVs
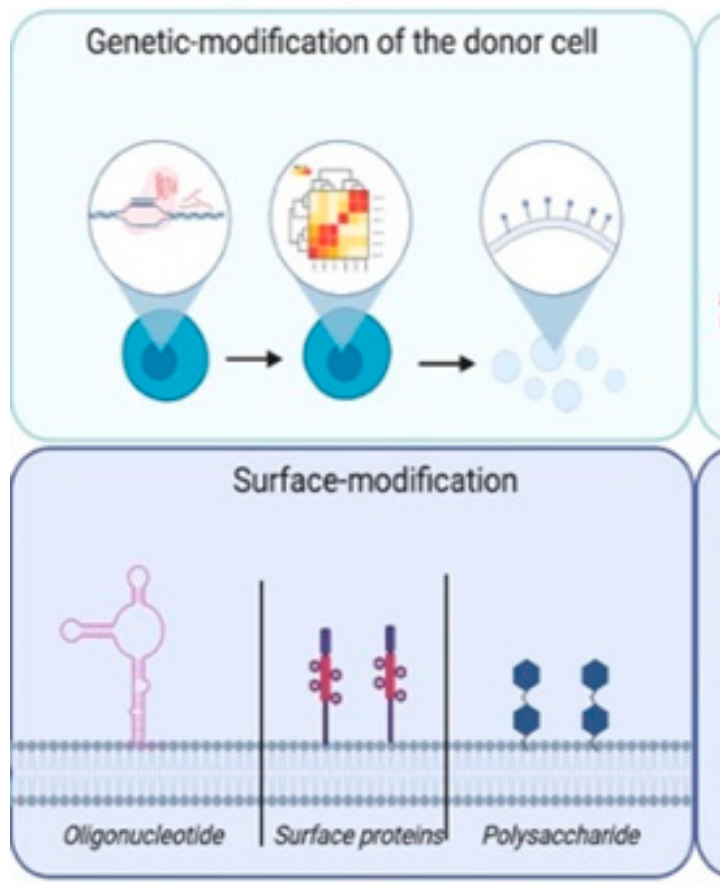

EVs in a clinical setting
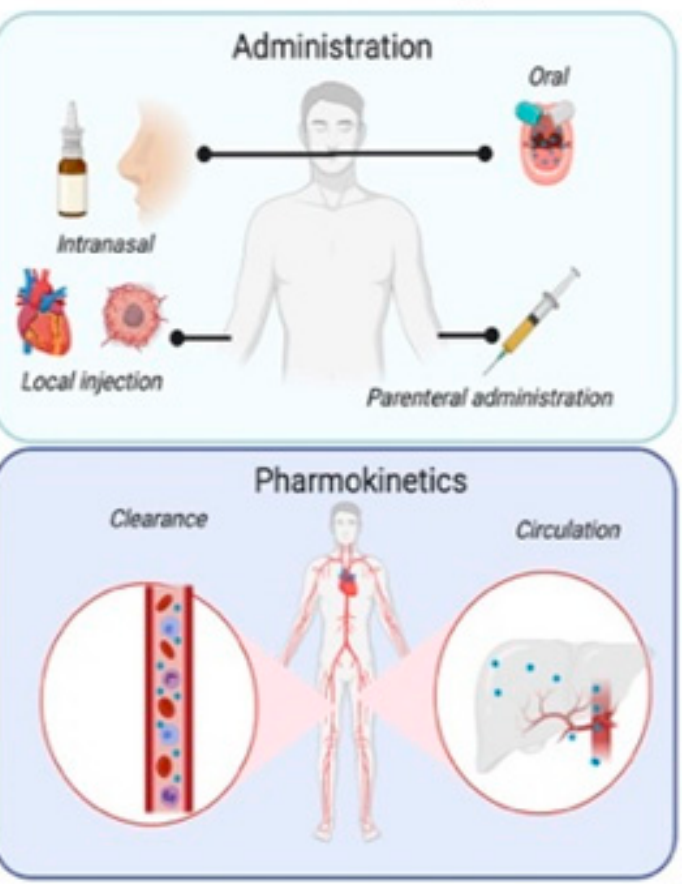

Figure 1. Conceptual overview of the different phases of EV-based therapy. EVs are produced and can be isolated from a wide range of cell types. EVs could be isolated from tissue biopsies, body fluids, as well as from animal and plant materials. To be used as a DDS, EVs can be isolated, for example, by ultracentrifugation or chromatography, depending on the type of EV and the source. In the second stage, the therapeutic agent will be loaded into the EVs. With pre-loading methods, the agent will be encapsulated into the EV in a natural way (i.e., using the machinery of the cell of origin). Post-loading approaches consist of physical or chemical methods, in which a disruption of the cell membrane of the already purified EV is induced. To improve the efficacy of the therapy, EVs can be modified, for instance, to increase the expression of certain receptors on the membrane, and this way its interaction with specific target cells or to avoid phagocytosis by the mononuclear phagocytic system. Finally, EVs are administered to the patients. The use of a proper route of administration may improve the pharmacokinetics of the drug by avoiding clearance or accumulation in off-target sites.

\subsection{Extracellular Vesicles}

EVs comprise a heterogeneous group of nanoparticles surrounded by bilayered phospholipidic membranes, which are released by eukaryotic and prokaryotic cells into the extracellular microenvironment [3]. In eukaryotic cells, EVs can be classified based on their mode of biogenesis and release into exosomes, microvesicles and apoptotic bodies [4]. Since several isolation and characterization techniques do not allow for a clear distinction between different types of EVs, and according to the position paper of the International Society for Extracellular Vesicles [5], the term extracellular vesicle (EV) will be preferred throughout this article, even in those cases where the original literature may refer to the vesicles as exosomes.

EVs carry proteins, nucleic acids, lipids and small molecules, whereby their specific cargo depends on the microenvironment and the pathophysiological state of the cell [6]. The transfer of EVs between cells may affect cell physiology but also play a role in the mechanisms of several diseases $[7,8]$. Besides their role in health and disease, EVs are considered as a rich source of biomarkers for the diagnosis of several diseases. More recently, the use of EVs as a new DDS, as well as a vehicle to deliver other therapeutic agents (e.g., oncolytic viruses) to specific tissues started to be investigated.

EVs offer several advantages in comparison to other carriers. Although synthetic particles such as liposomes already entered the market more than 20 years, their use exhibits significant disadvantages, such as high toxicity [9], high clearance and immunogenicity [10]. On the contrary, besides exhibiting 
lower toxicity [11], EVs may undergo less phagocytosis by macrophages and can therefore remain in circulation and in the tissues for a longer time. In this regard, EVs from antigen presenting cells carry both classes of the major histocompatibility complex (MHC) molecules at relatively high expression and can therefore stimulate $\mathrm{CD}^{+}$and $\mathrm{CD}^{+}$T-cells $[12,13]$. However, the T-cell stimulatory effect of these free EVs is 10-20 times less efficient compared with parent antigen presenting cells [14,15]. This would explain the lower capability of EVs of stimulating naïve T-cells and, this way, their low immunogenicity. Furthermore, T-cell activation requires more than only the presence of MHC molecules but also co-stimulation and T-cell receptor cross-linking, for which not all the required components are available at the surface of the EV $[12,16]$. Furthermore, EVs may avoid the endosomal pathways and lysosomal degradation more effectively than synthetic carriers do [17].

\section{Isolation and Production of EVs}

\subsection{Sources of EVS}

In vitro cell culture represents a common source of EVs for therapeutic purposes. Different cell types can be targeted by EVs from this origin and different effects may be observed. For instance, preclinical data from a mice study showed that intravenous injection of EVs from bone marrow mesenchymal stem cells (MSCs) suppressed hypoxia-induced pulmonary inflammation and ameliorated pulmonary hypertension [18]. Also, EVs from dendritic cells prevented allograft rejection in a model of renal transplantation in mice [19]. In addition, macrophage-derived EVs loaded with two types of chemotherapeutic agents showed positive results against triple negative breast cancer cells in both in vitro and in vivo mouse models [20]. These findings clearly exemplify that EVs isolated from cultured cells may have an effect on different target cells in vivo. Furthermore, this also highlights the potential of this type of EVs to be loaded with therapeutic agents with the aim of their delivery to particular target cells once administered to a whole organism.

Tumor cells represent another source of EVs, particularly promising in the field of cancer therapy. So far, one of the major limitations of cancer treatment is the enhanced chemoresistance exhibited by tumor cells [21], making it imperative to develop novel therapeutic strategies. In this regard, tropism of cancer-derived EVs could be useful. However, this tropism is not uniform for all types of EVs. In fact, some types of EVs are taken up by tissues or cell types different than the ones they originate from [22]. For instance, it was demonstrated that there is a heterologous and cross-species tumor-tropism for cancer-derived EVs. The uptake of lung cancer-derived EVs by colon carcinoma cell lines and vice versa was demonstrated in in vitro and in vivo models. Also, EVs derived from human lung cancer cells were taken up by breast tumors in a mice model [23]. This suggests that there could be a general tropism of cancer EVs for other neoplastic tissues. Towards, providing a personalized treatment strategy, special effort should be directed towards targeting the treatment to a particular cell type and reducing off-target effects. In this regard, the applications of EVs on cancer treatment have been extensively reviewed by Burgio et al. [24].

Regarding EV production from cell culture, it is important not only to carefully define the best cell source, but also the media, growth conditions, sera, type of culture (e.g., 2D or 3D), metabolic preconditioning and other culture conditions [25]. In this regard, a recent study described the difference between cells grown in a soft 3D matrix in comparison with those grown in a $2 \mathrm{D}$ plastic surface. Noteworthy, cytospin-A, an important cytoskeleton protein was described to regulate the softness of the EVs. The physical softness of the EVs from tumor-repopulating cells obtained from a 3D culture makes them more capable to penetrate and extravasate into the tumor parenchyma in a higher concentration and deliver more efficiently chemotherapeutic drugs. Therefore, cytospin-A could be a crucial player to improve the in vivo transport of EVs isolated from 3D cultures, eventually, leading to a better treatment outcome [26].

Cancer EVs can be isolated from fluids such as plasma [27-29]. For prostate cancer [30] and bladder cancer [31] urine may also constitute a source of vesicles. Also, gastric juice has been reported as 
a source of EVs in gastric cancer patients [32]. Finally, cancer cells cultured in vitro represent another useful source of EVs [33]. With the aim of treatment with autologous EVs, a tumor biopsy may be obtained as a source for the generation of the EVs. This approach may bear the advantage of delivering a higher number of specific cancer cell-derived EVs, than when vesicles are isolated from other biofluids.

Besides cancer cell EVs, other types of EVs can also be isolated from blood. Different types of therapeutic agents have already been loaded into blood-derived EVs like miRNAs [34], curcumin [35], or dopamine [36]. Serum derived EVs have demonstrated to deliver molecules in a more efficient manner than macrophages cell-derived EVs. Especially, foetal bovine serum-derived EVs were able to enter both the macrophage- and $\mathrm{T}$ cell-zones within lymph nodes, also displaying an increased delivery of stimulating biomolecules [37]. Other accessible fluids are urine [38] and saliva [39]. While the use of urinary EVs as a DDS has been briefly evaluated [40], the possibilities of saliva-derived EVs in a DDS are yet not known.

Furthermore, EVs can be isolated from vegetables, fruits and milk. EVs derived from bovine milk can be used to deliver anti-cancer drugs in rats and mice without toxic effects. Furthermore, this source of EVs may allow for scaling up production in a cost-effective way [41]. Similarly, ginger roots were used as EV source for administration in mice [42]. An extensive summary of all sources of EVs that have being used, including those used for in vivo administration, can be found in Tables 1 and 2 .

\subsection{Isolation of EVs}

So far, no universal isolation protocol has been established and different applications may require different types of EVs and, therefore, different isolation techniques. Currently available methods are based on ultracentrifugation, size chromatography, immunoaffinity capture and precipitation, whereby variable purity and yield can be obtained. Different isolation methods for EVs as well as their advantages and disadvantages have been reviewed elsewhere [43]. A frequent limitation of techniques based on size and centrifugation is the frequent overlap between different types of EVs, such as microvesicles and exosomes $[44,45]$. Thus, the use of these isolation methods requires multiple characterization assays before it can be concluded that a specific subset of EV was isolated [5].

Aqueous two-phase systems consisting of two mixed polymers with or without a salt solution have been described as an alternative to isolate EVs. For instance, polyethylene glycol (PEG) and dextran (DEX) were dissolved into urine and centrifuged at $1000 \times \mathrm{g}$. This resulted in the separation of the two polymers resulting in a top phase containing the PEG-rich solution and a bottom DEX-rich phase containing the EVs [46]. In comparison with the earlier mentioned techniques, the purity and the efficiency are higher and no specialized equipment is required, thus suggesting the potential of this approach to be scaled for bulk production.

\subsection{Loading of EVs with Therapeutic Agents}

\subsubsection{Post-Loading Approach}

This strategy is based on the loading of the therapeutic agent to EVs previously isolated from cells or another source of vesicles. It can be used, mainly, for synthetic molecules or small biomolecules. EV loading can take place passively or actively. The concept of passive loading is that isolated EVs are incubated with the therapeutic molecules, which will permeate into the EVs without additional stimulation. Active loading techniques are based on the application of a stimulus or adjuvant and can be divided into physically- and chemically-induced loading. Physically active methods such as electroporation, sonication, or extrusion disrupt the EV membranes to transfer the drug into the EV. Chemicals like saponin or transfection reagents can also be used to penetrate the membrane of the EV. A summary of the different post-loading methods as well as the therapeutic agents incorporated in each case is presented in Table 1. 


\subsubsection{Pre-Loading Approach}

In the pre-loading approach, the cellular machinery is used to load a therapeutic agent into the EVs during the vesicle biogenesis. As a result, secreted EVs will carry the therapeutic agent. One pre-loading alternative is the transfection or transduction of genetic material codifying a product of interest into EV-producing cells. As a consequence, the product will be overexpressed and encapsulated in the EVs. An example of this type of loading was described by Yuan et al. [47]. In this study, the genetic sequence of the tumor necrosis factor-related apoptosis inducing ligand (TRAIL) was transduced with a lentivirus and expressed in mesenchymal stromal cells. The secreted EVs from these cells carried TRAIL and induced apoptosis with high efficiency and selectivity in three different cancer cell lines. Noteworthy, with this type of loading method, it may be difficult to control the concentration that is loaded into the EVs as they may depend on multiple factors including transfection or transduction efficiency and cell viability. Hereby, models stably expressing the product of interest may represent an advance towards obtaining a more standardized pre-loading into the EVs. For the pre-loading of EVs with a protein cargo, an innovative approach is the technique called 'exosomes for protein loading via optically reversible protein-protein interactions' (EXPLORs) [48]. The principle is based on two different proteins. Cryptochrome 2 (CRY2) is fused covalently to the intended cargo protein. The second component is the exosome-associated tetraspanin CD9 bearing a special variant of cryptochrome-interacting basic-helix-loop-helix 1 (CIBN). The fusion between these two structures is induced by excitation with blue light $(488 \mathrm{~nm})$. Following the formation of EVs, the light source is removed. Thus, the CIBN complex detaches from the CD9 and results in the release of the cargo protein of interest into the intraluminal space. This approach may be particularly useful to enrich the EVs with therapeutic proteins which are not loaded into the EVs under physiological conditions [48]. The EXPLOR method is graphically depicted in Figure 2.
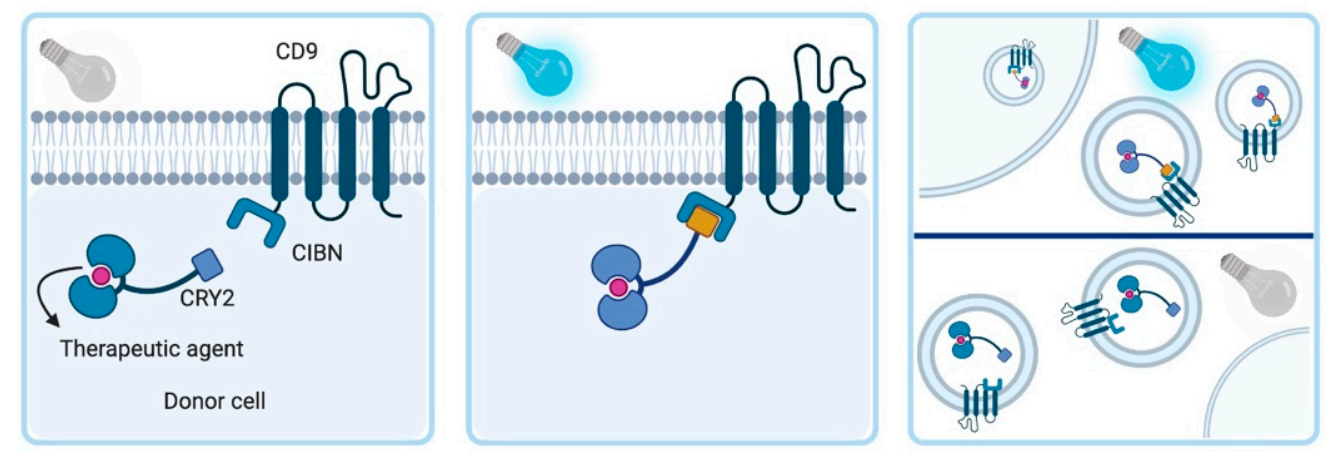

Figure 2. Principle of the EXPLORs technique. The binding between the CD9 complex and the CRY2 coupled to the therapeutic protein is induced in the donor cell by exposure to blue light $(488 \mathrm{~nm})$. Within $15 \mathrm{~s}$, the cargo-protein is guided to the inner surface of the cell membrane and binds to the CIBN. The secreted EVs can be isolated, purified, and used for therapeutic purposes. Abbreviations: CIBN: truncated version of CRY-interacting basic-helix-loop-helix 1 (CIB1) protein; CRY2: Cryptochrome 2.

The preloading strategy may also be applied to load vesicles aimed at delivering oncolytic viruses. Although this type of viruses can selectively infect and kill cancer cells, the host immune system may detect their presence and neutralize them, thus interfering with the desired effect [49]. Gould et al. [50] described the use of EVs as a virus carrier. Virus-loaded EVs induced infection in cancer cells, which also led to the infection of other autologous cancer cells. This principle was also tested in vivo in a lung cancer xenograft model and also combined with the chemotherapeutic agent paclitaxel. The combination showed a significantly higher antitumoral efficacy in comparison to the virus alone [51]. 
Table 1. Strategies for the loading of EVs with therapeutic agents. Detailed are different studies describing the loading of EVs with therapeutic agents. The specific loading method, the source of EVs as well as the therapeutic agent or experimental cargo are mentioned. Subsequently, the method used to evaluate the loading efficiency, if known, is indicated. Finally, the model where the generated EVs were applied is indicated. Abbreviations: DNA-CH: cholesterol-coupled DNA; dsDNA: double stranded DNA; EXPLORs: exosomes for protein loading via optically reversible protein-protein interactions; hESC: human embrionary stem cell; HPLC: High-performance liquid chromatography; HUVEC: human umbilical vein endothelial cell; miRNA: micro RNA; LC-MS: Liquid chromatography-mass spectrometry; MRSA: Methicillin-resistant Staphylococcus aureus; MSC: mesenchymal stem cell; siRNA: small interfering RNA; ssDNA: single-stranded DNA; TAMEL: Targeted and modular EV loading; t-PA: tissue-plasminogen activator; UPLC: Ultra-Performance Liquid Chromatography.

\begin{tabular}{|c|c|c|c|c|c|}
\hline Loading Method & EV Source & $\begin{array}{l}\text { Therapeutic Agent or } \\
\text { Experimental Cargo }\end{array}$ & Loading Efficiency & Model & Ref. \\
\hline \multirow{17}{*}{ Passive incubation } & $\begin{array}{l}\text { Cell culture } \\
\text { (LIM1215 cells) }\end{array}$ & Doxorubicin & Spectrofluorometry & Cell culture, mice tumor xenograft & [52] \\
\hline & Cell culture (HEI-OC1 cells) & $\begin{array}{c}\text { Aspirin, arachidonic acid, } \\
\text { eicosapentaenoic acid, } \\
\text { docosohexaenoic acid, linoleic acid, } \\
\text { lipoxin, resolvin D1 }\end{array}$ & & & [53] \\
\hline & Cell culture (HEI-OC1 cells) & Dexamethasone & & & [54] \\
\hline & Cell culture (HEK293T cells) & siRNA and rhodamine & Spectrofluorometry & & [55] \\
\hline & Cell culture (LNCaP and PC-3 cells) & Paclitaxel & UPLC & Cell culture & {$[56]$} \\
\hline & $\begin{array}{l}\text { Cell culture (LL/2, MC-38, A549 cells), } \\
\text { liver tissue }\end{array}$ & Oncolytic adenovirus & & $\begin{array}{l}\text { Cell culture and mice with colon } \\
\text { adenocarcinoma xenograft }\end{array}$ & [23] \\
\hline & $\begin{array}{c}\text { Cell culture (MDA-MB-231, MSCs, hESCs, } \\
\text { HUVECs) }\end{array}$ & Different porphyrins & & Cell culture & [57] \\
\hline & Cell culture (MSCs) & Doxorubicin & Spectrophotometry & Cell culture & [58] \\
\hline & Cell culture (MSC) & miR-210 & & Mice & [59] \\
\hline & Cell culture (MSC) & $\begin{array}{l}\text { Nanoparticles loaded with } \\
\text { curcumin }\end{array}$ & Spectrophotometry & & [60] \\
\hline & Cell culture (Neuro2A, dendritic cells) & siRNA & Spectrofluorometry & Cell culture & [61] \\
\hline & Cell culture (Raw 264.7 cells) & Linezolid & HPLC & Mice with MRSA infection & [62] \\
\hline & Cell culture (Raw 264.7 cells) & Paclitaxel, doxorubicin & HPLC & $\begin{array}{l}\text { Cell culture, different xenograft } \\
\text { mouse models }\end{array}$ & [20] \\
\hline & Cell culture (Raw 264.7 cells) & Paclitaxel, doxorubicin & HPLC & MDCK-MDR1 cells; mice & [63] \\
\hline & Cell culture (Raw 264.7 cells) & Catalase & $\begin{array}{l}\text { Catalase enzymatic } \\
\text { activity }\end{array}$ & Cell culture, mice & [64] \\
\hline & Cell culture (THP-1) & $\begin{array}{c}\text { Doxorubicin, t-PA, photosensitizer } \\
\text { molecules }\end{array}$ & Spectrofluorometry & Cell culture & [65] \\
\hline & Cell culture (U87 cells) & Paclitaxel & HPLC & Cell culture & [66] \\
\hline
\end{tabular}


Table 1. Cont

\begin{tabular}{|c|c|c|c|c|c|}
\hline Loading Method & EV Source & $\begin{array}{l}\text { Therapeutic Agent or } \\
\text { Experimental Cargo }\end{array}$ & Loading Efficiency & Model & Ref. \\
\hline \multirow{4}{*}{ Passive incubation } & Platelets & Doxorubicin & Spectrofluorometry & Cell culture & [67] \\
\hline & Bovine milk & $\begin{array}{l}\text { Withaferin, anthocyanidins, } \\
\text { curcumin, paclitaxel, docetaxel }\end{array}$ & Spectrophotometry, UPLC & $\begin{array}{l}\text { Rats, mice with different } \\
\text { xenograft variants }\end{array}$ & [41] \\
\hline & Bovine milk and cell culture & Curcumin & & Cell culture & [68] \\
\hline & Blood & Dopamine & LC-MS & Mice & [36] \\
\hline \multirow{18}{*}{ Electroporation } & Cell culture (Dendritic cells) & Let-7-miRNA and siRNA & qPCR & Mice with breast tumor xenograft & [69] \\
\hline & Cell culture (HEI-OC1 cells) & $\begin{array}{c}\text { Aspirin, arachidonic acid, } \\
\text { eicosapentaenoic acid, } \\
\text { docosohexaenoic acid, linoleic acid, } \\
\text { lipoxin, resolvin D1 }\end{array}$ & & & [53] \\
\hline & Cell culture (HEK293T cells) & Doxorubicin & Spectrofluorometry & $\begin{array}{l}\text { Cell culture, mice with breast } \\
\text { tumor xenograft }\end{array}$ & [70] \\
\hline & Cell culture (HEK293T cells) & siRNA, rhodamine & Spectrofluorometry & & [55] \\
\hline & Cell culture (HEK293T cells) & siRNA & Spectrofluorometry & Cell culture & [71] \\
\hline & Cell culture (HEK293T cells) & siRNA & & Cell culture & [72] \\
\hline & Cell culture (HEK293T cells) & Doxorubicin & Spectrofluorometry & Cell culture & [73] \\
\hline & Cell culture (HEK293T cells, HUVECs) & dsDNA & Spectrophotometry & Cell culture & [74] \\
\hline & $\begin{array}{c}\text { Cell culture (MDA-MB-231, MSCs, hESCs, } \\
\text { HUVECs) }\end{array}$ & Different porphyrins & & Cell culture & [57] \\
\hline & Cell culture (MDA-MB-231 cells) & $\begin{array}{l}\text { Superparamagnetic iron } \\
\text { nanoparticles and olaparib }\end{array}$ & & $\begin{array}{l}\text { Cell culture, mice with breast } \\
\text { tumor xenograft }\end{array}$ & [75] \\
\hline & Cell culture (MSCs) & Doxorubicin & Spectrofluorometry & $\begin{array}{l}\text { Mice with multiple xenograft } \\
\text { variants }\end{array}$ & [76] \\
\hline & $\begin{array}{l}\text { Cell culture (Normal intestinal fetal } \\
\text { human cells) }\end{array}$ & miRNA-128-3p & qPCR & $\begin{array}{l}\text { Cell culture, mice with colon } \\
\text { tumor xenograft }\end{array}$ & [77] \\
\hline & Cell culture (Raw 264.7 cells) & $\begin{array}{l}\text { Superparamagnetic iron } \\
\text { nanoparticles loaded } \\
\text { with curcumin }\end{array}$ & Spectrophotometry & Mice bearing glioma cells & [78] \\
\hline & Cell culture (Raw 264.7 cells) & Paclitaxel, doxorubicin & HPLC & MDCK-MDR1 cells; mice & [63] \\
\hline & Cell culture (3T3 and A549 cells) & siRNA & & Cell culture & [79] \\
\hline & Plasma and cell culture & $\begin{array}{l}\text { Curcumin, siRNA, DNA-CH, } \\
\text { miR-145 mimics }\end{array}$ & & Mice with lung tumor xenograft & [35] \\
\hline & Plasma & miR-31-5p, miR-451a & & Cell culture, & [34] \\
\hline & Serum & Tyrosinase-related-protein-2 & Spectrofluorometry & Cell culture & [80] \\
\hline
\end{tabular}


Table 1. Cont

\begin{tabular}{|c|c|c|c|c|c|}
\hline Loading Method & EV Source & $\begin{array}{l}\text { Therapeutic Agent or } \\
\text { Experimental Cargo }\end{array}$ & Loading Efficiency & Model & Ref. \\
\hline \multirow{11}{*}{ Sonication } & Cell culture (HEI-OC1 cells) & Dexamethasone & & & [54] \\
\hline & Cell culture (HEK293T, MCF7 cells) & siRNA, miRNA, ssDNA & & Cell culture & [81] \\
\hline & Cell culture (IC21 cells) & Tripeptidyl peptidase- 1 & Enzymatic activity & Cell culture, mice & [82] \\
\hline & Cell culture (J774A.1 cells) & Doxorubicin & & Cell culture & [83] \\
\hline & Cell culture (Human fetal lung fibroblast 1) & Erastin & HPLC & Cell culture & [84] \\
\hline & Cell culture (Raw 264.7 cells) & Catalase & $\begin{array}{c}\text { Catalase enzymatic } \\
\text { activity }\end{array}$ & Cell culture, mice & [64] \\
\hline & Cell culture (Raw 264.7 cells) & Paclitaxel & HPLC & Cell culture, mice & [85] \\
\hline & Cell culture (Raw 264.7 cells) & Paclitaxel, doxorubicin & HPLC & MDCK-MDR1 cells; mice & [63] \\
\hline & Cell culture (Raw 264.7 cells) & Paclitaxel, doxorubicin & HPLC & $\begin{array}{l}\text { Cell culture, mice with breast } \\
\text { cancer xenograft }\end{array}$ & [20] \\
\hline & Cell culture (U937 cells) & Dexamethasone & HPLC & Cell culture, mice & [86] \\
\hline & Cell culture (U87 cells) & Paclitaxel & HPLC & Cell culture & [66] \\
\hline Lipofection & Bovine milk & siRNA & & Zebrafish and mice & [87] \\
\hline \multirow{3}{*}{ Transfection } & Cell culture (A172 cells) & siRNA & RT-PCR & Mice & [88] \\
\hline & Cell culture (HEK293T cells) & Anti-miR-214 & & Cell culture, mice & [89] \\
\hline & Human peripheral blood cells & miR-21 & & Cell culture, mice & [90] \\
\hline \multirow{4}{*}{$\begin{array}{c}\text { Saponin } \\
\text { permeabilization }\end{array}$} & Cell culture (IC21 cells) & Tripeptidyl-peptidase-1 & Enzymatic activity & Cell culture, mice & [82] \\
\hline & $\begin{array}{c}\text { Cell culture (MDA-MB-231, MSCs, } \\
\text { hESCs, HUVECs) }\end{array}$ & Different porphyrins & & Cell culture & [57] \\
\hline & Cell culture (Raw 264.7 cells) & Catalase & $\begin{array}{l}\text { Catalase enzymatic } \\
\text { activity }\end{array}$ & Cell culture, mice & [64] \\
\hline & Serum & Tyrosinase-related-protein-2 & Spectrofluorometry & Cell culture & [80] \\
\hline pH-gradient & Neutrophils & Piceatannol & HPLC & Cell culture, mice & [91] \\
\hline \multirow{2}{*}{ Extrusion } & $\begin{array}{c}\text { Cell culture (MDA-MB-231 cells, MSCs, } \\
\text { hESCs, HUVECs) }\end{array}$ & Different porphyrins & & Cell culture & [57] \\
\hline & Cell culture (Raw 264.7 cells) & Catalase & $\begin{array}{c}\text { Catalase enzymatic } \\
\text { activity }\end{array}$ & Cell culture, mice & [64] \\
\hline Freeze-thaw cycles & Cell culture (Raw 264.7 cells) & Catalase & $\begin{array}{l}\text { Catalase enzymatic } \\
\text { activity }\end{array}$ & Cell culture, mice & [64] \\
\hline
\end{tabular}


Table 1. Cont

\begin{tabular}{|c|c|c|c|c|c|}
\hline Loading Method & EV Source & $\begin{array}{l}\text { Therapeutic Agent or } \\
\text { Experimental Cargo }\end{array}$ & Loading Efficiency & Model & Ref. \\
\hline $\begin{array}{l}\text { Hypotonic dialysis } \\
\text { and extrusion }\end{array}$ & $\begin{array}{c}\text { Cell culture (MDA-MB-231 cells, MSCs, } \\
\text { hESCs, HUVECs) }\end{array}$ & Different porphyrins & & Cell culture & [57] \\
\hline \multirow{8}{*}{ Transfection } & Cell culture (HEK293T cells) & miR-21 sponge & RT-qPCR & Cell culture, rats & [92] \\
\hline & Cell culture (HEK293T cells) & miR-199a-3p & RT-qPCR & Mice & [11] \\
\hline & Cell culture (HEK293T cells) & miR-199a-3p & RT-qPCR & Cell culture & [93] \\
\hline & Cell culture (HEK293T cells) & Cre recombinase & RT-qPCR & Cell culture & [94] \\
\hline & Cell culture (IC21 cells) & Tripeptidyl-peptidase-1 & Enzymatic activity & Cell culture, mice & [82] \\
\hline & $\begin{array}{l}\text { Cell culture (Normal intestinal fetal } \\
\text { human cells) }\end{array}$ & miRNA-128-3p & qPCR & $\begin{array}{l}\text { Cell culture, mice with colon } \\
\text { tumor xenograft }\end{array}$ & [77] \\
\hline & Cell culture (MSCs) & Anti-miR-222/223 & & Mice with breast tumor xenografts & [95] \\
\hline & Cell culture (4T1, SKBR3, HepG2 cells) & Anti-miR-21 & Fluorescence microscopy & Cell culture & [96] \\
\hline TAMEL & Cell culture (HEK293T cells) & RNA & & Cell culture & [97] \\
\hline ExPLORs & Cell culture (HEK293T cells) & Recombinant luciferase & Luciferase activity & Cell culture, mice & [48] \\
\hline
\end{tabular}




\section{Administration and Biodistribution}

Different routes have been evaluated for EV administration in experimentation animals (Table 2). Intravenous administration constitutes the most frequent route and has been reported for the administration of vesicles isolated from different sources, whereby mesenchymal stem cells (MSCs) constitute the most common one [98,99]. EVs obtained from this source have been more extensively studied for their potential in regenerative medicine (reviewed by Campanella et al., [100]). However, they may also be used for the treatment of other disorders. Intravenous administration of MSC-derived EVs resulted in the presence of EVs or in the observation of EV-related effects in a wide range of organs and tissues. Noteworthy, the delivery of therapeutic agents to the central nervous system (CNS) constitutes a challenge due to the structural properties of the blood brain barrier as well as the presence of drug extruding transporters in the brain endothelial cells, impairing the penetration of xenobiotics [101]. Hereby, intravenous administration of EVs from MSCs has been repeatedly successful towards the delivery of EVs, for instance, carrying different miRNAs, to the CNS [59,102-104]. Similarly, other studies described the intravenous delivery to the CNS of EVs isolated from adipose tissue stem cells [105], HEK293T cells [106], urinary stem cells [40], dendritic cells [107] and rat serum [108]. However, it is worth mentioning that most of these did not evaluate whether the same experimental approach may result in effects in other tissues. In this regard, other studies described the intravenous delivery of EVs from MSC and adipose stem cells to other tissues such as such as pulmonary vasculature [109], carotid artery [110], heart [111], lungs [112], pancreas [113], liver [114] and colon [115]. Based on this evidence, intravenous administration of EVs from MSC or adipose stem cell does not appear to provide enough specificity to target one particular tissue or organ. For this purpose, further refinements of the production strategy may be required, for example vesicle engineering (see Section 5).

Alternatively, intravenous administration of EVs isolated from sources with a closer relation to the target tissue may be a possibility towards obtaining a higher specificity. Recent reports described the delivery of urinary EVs to the kidney [116], EVs from Schwann cells to peripheral nerves [117], serum EVs from mice with acute lung injury to the lungs [118] and EVs from cardiac progenitor cells to the heart [119-121]. Also, intravenous delivery to the CNS has been observed for vesicles isolated from microglial cells [122,123] and mouse brain endothelial cells [124].

The intravenous route has been also reported to be useful in the delivery of cancer-derived EVs to tumoral tissue [125]. Interestingly, administration of tumor exosome-based nanoparticles loaded with doxorubicin resulted in a reduction in tumor volume and increased survival time in mice xenograft models for hepatocellular carcinoma and for breast cancer, when compared to other therapeutic alternatives. Importantly, for hepatoma xenografts, the antitumoral effect of the nanoparticles was even higher than that of intravenous free doxorubicin. In addition, the use of the same nanoparticles resulted in a reduction in lung metastasis in a mice xenograft model for melanoma. Importantly, the systemic toxicity of the nanoparticle-based strategy was lower than for the administration of free doxorubicin [126]. Conversely, it is well-acknowledged that EVs, as key players in cell-cell communication, may play a role in cancer pathogenesis, promoting initiation and progression [127]. Further research should aim at elucidating the safety of EV-based cancer therapy approaches, especially in long-term studies. Furthermore, a deeper knowledge of the role of EVs in cancer pathogenesis and the components of the cargo responsible for the tumor-stimulatory effects, may also contribute to the engineering and design of effective and safe EV-based therapeutic strategies for cancer.

Intranasal administration represents the second most frequently reported route. Delivery of MSC-derived EVs to the CNS has been described in several studies [128-132]. In line with these findings, Scholl et al., [133] described the intranasal delivery of glioma-derived EVs obtained in vitro to glioma tissue in rats. The advantages of this administration route may be particularly important in the treatment of neurodegenerative disorders [134]. Also, successful intranasal EV delivery to the lungs has been reported $[135,136]$. To date, comparative evidence of the intranasal route versus other administration routes is limited. In a recent report, Bonafede et al., [105] compared the administration of 
adipose stem cell-derived EVs intranasally and intravenously in a murine model of amyotrophic lateral sclerosis. Most protective effects were achieved similarly both for the intravenous and the intranasal administration. On the contrary, the intranasal administration was more effective in reducing astrocyte activation [105].

The subcutaneous administration of EVs has been described for the generation of a systemic immune response in mice administered with vesicles isolated from Echinostoma caproni [137]. Also, subcutaneous administration of EVs from adipose stem cells resulted in an alleviating effect in a mice model of atopic dermatitis. Here, comparative experiments were performed and similar results were observed for the intravenous and the subcutaneous pathways [138]. Systemic effects have also been reported for the intramuscular administration of EVs in chicken [139]. In addition, the intramuscular injection of EVs resulted in the delivery of vesicles to the kidneys [140]. As expected, also local effects of the vesicles at the muscular level were observed [141,142].

A comparative study from Brossa et al., [99] described, however, a reduced accumulation of MSC and liver stem cells derived EVs in subcutaneous renal tumors following intraperitoneal administration respect to the accumulation after intravenous administration. Also, Zhou et al. [143] compared both administration routes and observed an enrichment of intravenously-administered EVs in liver, spleen and lungs. Intraperitoneal administration resulted in a more disperse distribution pattern, whereby visceral adipose tissue displayed a significant accumulation of vesicles. Based on these findings, this strategy could be used in the treatment of diseases associated to visceral adipose tissue (e.g., metabolic syndrome).

Oral administration was described for EVs from bovine-milk in a mice model. Six hours post-administration, the vesicles were localized in the liver, heart, spleen, lungs and kidneys [144]. Furthermore, a comparative study between oral and intravenous administration of bovine-milk EVs described an enrichment of intravenously administered vesicles in the spleen, liver and, to a lower extent, lungs of mice. Conversely, the enrichment took place primarily in the liver, when the same EVs were administered orally [145]. These findings highlight the oral route as a possible strategy to simplify the use of EVs as DDS, without requiring specialized healthcare personnel.

Local injection of EVs may reduce the off-target delivery and increase the exposure of the target tissue and reduce the clearance of the vesicles, compared to systemic administration. For instance, intraocular and subconjunctival injection of MSC-derived EVs resulted in the delivery of the vesicles to the retina in a rabbit model of diabetes-induced retinopathy [146]. Intramyocardial injection has also been used for MSC-derived EVs, in a rat model of acute myocardial infarction [147]. Also, intrathecal injection was described for the delivery of EVs to peripheral nerves in rats [148]. Likewise, intratumoral administration resulted in a clear enrichment of EVs in the tumor, absence of EVs in liver and spleen and reduced clearance, compared with the intravenous administration [149].

In addition to the route of administration, EV size is an additional factor that could influence the biodistribution profile. For example, larger EVs accumulated in higher concentrations in bones and lymph nodes compared to smaller EVs. Nonetheless, the contribution of the molecular compositions of the EVs to this accumulation profile cannot be excluded [150].

An extensive summary of the individual studies performed, highlighting the source of EVs, their route of administration and the tissues affected under each treatment strategy can be found in Table 2. 
Table 2. Administration routes for EVs in vivo. Detailed are different studies using in vivo models where EVs were administered. Described are the administration routes, the experimental model, the source of EVs, the therapeutic cargo (when known), and the target tissue of the EVs or the EV-related effects. While in some cases a therapeutic cargo was known, in other cases the EV itself was the therapeutic agent and no particular component of the cargo was specified as responsible for the effect observed. Abbreviations: AdSC: adipose tissue-derived stem cells; CNS: central nervous system; miR: micro RNA; MSC: mesenchymal stem cells.

\begin{tabular}{|c|c|c|c|c|c|}
\hline Administration Route & Experimental Model & Source of EVs & Therapeutic Cargo & Target Tissues & Reference \\
\hline \multirow{23}{*}{ Intravenous } & \multirow{23}{*}{ Mice } & Plasma & & Liver & [151] \\
\hline & & Serum & miR-124 & CNS & [152] \\
\hline & & Serum & & Lung & [118] \\
\hline & & Serum & & Systemic effects & [153] \\
\hline & & $\begin{array}{l}\text { Mice serum, supernatant of } \\
\text { cultured myotubes }\end{array}$ & $\operatorname{miR}-21$ & Kidney & [154] \\
\hline & & Blood & Dopamine & $\mathrm{CNS}$ & [36] \\
\hline & & Urine & Klotho & Kidney & [116] \\
\hline & & Milk & & Liver, spleen, heart, lungs & [145] \\
\hline & & MSC & Paclitaxel & Subcutaneous tumors and distant metastases & [155] \\
\hline & & MSC & & Heart & [111] \\
\hline & & MSC & & Liver & [156] \\
\hline & & MSC & miR-210 & Brain & [59] \\
\hline & & MSC & miR-let7 & Atherosclerotic plaque & [157] \\
\hline & & MSC & miR-125b & Heart & [158] \\
\hline & & MSC & & Bone marrow & [159] \\
\hline & & MSC & & CNS & [160] \\
\hline & & MSC, liver stem cells & & Subcutaneous tumor & [99] \\
\hline & & AdSC & $\operatorname{miR}-199^{a}$ & Orthotopic tumor & [161] \\
\hline & & AdSC & & CNS & [105] \\
\hline & & AdSC & miR-17 & Liver & [114] \\
\hline & & AdSC & & Skin & {$[138,162]$} \\
\hline & & Bone marrow stromal cells & & Liver, lungs, bone & [163] \\
\hline & & HEK293T cells & Anti-miR-214 & Subcutaneous tumor & [89] \\
\hline
\end{tabular}


Table 2. Administration routes for EVs in vivo. Detailed are different studies using in vivo models where EVs were administered. Described are the administration routes, the experimental model, the source of EVs, the therapeutic cargo (when known), and the target tissue of the EVs or the EV-related effects. While in some cases a therapeutic cargo was known, in other cases the EV itself was the therapeutic agent and no particular component of the cargo was specified as responsible for the effect observed. Abbreviations: AdSC: adipose tissue-derived stem cells; CNS: central nervous system; miR: micro RNA; MSC: mesenchymal stem cells.

\begin{tabular}{|c|c|c|c|c|c|}
\hline Administration Route & Experimental Model & Source of EVs & Therapeutic Cargo & Target Tissues & Reference \\
\hline \multirow{22}{*}{ Intravenous } & & HEK293T cells & Curcumin, miR-143a & Tumor cells & [164] \\
\hline & & HEK293T cells & miR-199a-3p & Subcutaneous tumor & [165] \\
\hline & & HEK293 cells & & Mammary tumor & {$[166]$} \\
\hline & & Dendritic cells & & Spleen & [167] \\
\hline & & Dendritic cells & siRNA & Brain & [107] \\
\hline & & Immature dendritic cells & Doxorubicin & Mammary tumor & [168] \\
\hline & & Mouse brain endothelial cells & miR-126 & CNS & [124] \\
\hline & & Endothelial colony forming cells & $\operatorname{miR}-486-5 p$ & Kidney & [169] \\
\hline & & Gastric epithelial cells & & Aorta & {$[170]$} \\
\hline & & Neural primary stem cells & & CNS & {$[171]$} \\
\hline & & BMD2a cells & & Lungs, liver, spleen, brain & [172] \\
\hline & & Liver & miR-130a-3p & Systemic effects & [173] \\
\hline & & Schwann cells & & Peripheral nerves & [117] \\
\hline & & Astrocytes & & CNS & [174] \\
\hline & & Microglial cells & miR-124-3p & CNS & [122] \\
\hline & & Breast cancer cells & miR-126 & Lung cancer cells & [125] \\
\hline & & $\begin{array}{l}\text { Tumor-cell exocytosed-exosome } \\
\text { biomimetic porous silicon } \\
\text { nanoparticle }\end{array}$ & Doxorubicin & Tumor cells & [126] \\
\hline & & Gastric cancer cells & & Blood myeloid-derived suppressor cells & [175] \\
\hline & & Pancreas carcinoma cells & & Liver, spleen, lungs & [176] \\
\hline & & Macrophages & $\begin{array}{l}\text { Brain-derived } \\
\text { neurotrophic factor }\end{array}$ & CNS & [177] \\
\hline & & L929 cells & Methotrexate & Glioblastoma tissue & [178] \\
\hline & & Ginger roots & siRNA & Subcutaneous tumor & [42] \\
\hline
\end{tabular}


Table 2. Administration routes for EVs in vivo. Detailed are different studies using in vivo models where EVs were administered. Described are the administration routes, the experimental model, the source of EVs, the therapeutic cargo (when known), and the target tissue of the EVs or the EV-related effects. While in some cases a therapeutic cargo was known, in other cases the EV itself was the therapeutic agent and no particular component of the cargo was specified as responsible for the effect observed. Abbreviations: AdSC: adipose tissue-derived stem cells; CNS: central nervous system; miR: micro RNA; MSC: mesenchymal stem cells.

\begin{tabular}{|c|c|c|c|c|c|}
\hline Administration Route & Experimental Model & Source of EVs & Therapeutic Cargo & Target Tissues & Reference \\
\hline \multirow{25}{*}{ Intravenous } & \multirow{25}{*}{ Rats } & Serum & & CNS & {$[108]$} \\
\hline & & MSC & miR-544 & CNS & {$[102]$} \\
\hline & & MSC & $\begin{array}{l}\text { CC chemokine receptor } \\
\text { type } 2\end{array}$ & CNS & [179] \\
\hline & & MSC & & $\mathrm{CNS}$ & [180] \\
\hline & & MSC & & CNS & [181] \\
\hline & & MSC & miR-17-92 cluster & CNS & [104] \\
\hline & & MSC & & Pulmonary vasculature & [109] \\
\hline & & MSC & & Colon & [115] \\
\hline & & MSC & & Vein graft & [182] \\
\hline & & MSC & & Heart & [183] \\
\hline & & MSC & & Lungs & [112] \\
\hline & & MSC & miR-29b & Spinal cord & [184] \\
\hline & & MSC & & Pancreas & [113] \\
\hline & & MSC & & Carotid artery & [110] \\
\hline & & MSC & & Bone & [185] \\
\hline & & AdSC & & Penile tissue & [186] \\
\hline & & AdSC & miR-126 & CNS & [187] \\
\hline & & AdSC & & Brain, spleen & [188] \\
\hline & & AdSC & & Systemic effects & [189] \\
\hline & & AdSC & & CNS & [190] \\
\hline & & Human urinary stem cells & miR-26a & CNS & [40] \\
\hline & & $\begin{array}{l}\text { Human fetal amniotic fluid } \\
\text { stem cells }\end{array}$ & & Heart & [191] \\
\hline & & Cardiac progenitor cells & miR-146a & Heart & [119] \\
\hline & & Cardiac progenitor cells & & Cardiomyocytes & [120] \\
\hline & & Cardiac stem cells & & Heart & [121] \\
\hline
\end{tabular}


Table 2. Administration routes for EVs in vivo. Detailed are different studies using in vivo models where EVs were administered. Described are the administration routes, the experimental model, the source of EVs, the therapeutic cargo (when known), and the target tissue of the EVs or the EV-related effects. While in some cases a therapeutic cargo was known, in other cases the EV itself was the therapeutic agent and no particular component of the cargo was specified as responsible for the effect observed. Abbreviations: AdSC: adipose tissue-derived stem cells; CNS: central nervous system; miR: micro RNA; MSC: mesenchymal stem cells.

\begin{tabular}{|c|c|c|c|c|c|}
\hline Administration Route & Experimental Model & Source of EVs & Therapeutic Cargo & Target Tissues & Reference \\
\hline \multirow{9}{*}{ Intravenous } & \multirow{7}{*}{ Rats } & Human iPSCs & & Bone & [192] \\
\hline & & Urinary stem cells & & Kidney & [193] \\
\hline & & Aortic adventitial fibroblasts & miR-155-5p & Aorta and mesenteric artery & [194] \\
\hline & & HEK293T cells & miR-21 antisense & CNS & [106] \\
\hline & & HEK293T cells & siRNA & $\mathrm{CNS}$ & [195] \\
\hline & & Human renal tubular cells & & Kidney & [196] \\
\hline & & Renal cells & & Kidney & [197] \\
\hline & Patients with COVID-19 & MSC & & Systemic effects & [198] \\
\hline & Monkeys & MSC & & CNS & [199] \\
\hline Intravenous (in utero) & Ovine fetuses & MSC & & Brain & [200] \\
\hline \multirow{12}{*}{ Intranasal } & \multirow{8}{*}{ Mice } & MSC & & CNS & [201-203] \\
\hline & & AdSC & & CNS & [105] \\
\hline & & ESC & Curcumin & CNS & [204] \\
\hline & & Astrocytes & siRNA & Microglia & [88] \\
\hline & & Amnion epithelial cells & & Lungs & [205] \\
\hline & & Macrophages & & Lungs & {$[135,206]$} \\
\hline & & $\begin{array}{l}\text { EL4, 3T3L1, 4T1, CT26 } \\
\text { and A20 cells }\end{array}$ & Curcumin, JSI-124 & CNS & [132] \\
\hline & & Bronchoalveolar lavage fluid & & Lungs, systemic effects & {$[136,207]$} \\
\hline & \multirow{4}{*}{ Rats } & MSC & & CNS & $\begin{array}{l}{[128,130,} \\
131,208]\end{array}$ \\
\hline & & MSC & siRNA & CNS & [129] \\
\hline & & C6 Glioma cells & & Glioma & [133] \\
\hline & & Human teeth stem cells & & CNS & [134] \\
\hline Intraperitoneal & Mice & Liver stem cells, MSC & & Subcutaneous tumor & [99] \\
\hline Intramyocardial & Rats & MSC & & Heart & [147] \\
\hline
\end{tabular}


Table 2. Administration routes for EVs in vivo. Detailed are different studies using in vivo models where EVs were administered. Described are the administration routes, the experimental model, the source of EVs, the therapeutic cargo (when known), and the target tissue of the EVs or the EV-related effects. While in some cases a therapeutic cargo was known, in other cases the EV itself was the therapeutic agent and no particular component of the cargo was specified as responsible for the effect observed. Abbreviations: AdSC: adipose tissue-derived stem cells; CNS: central nervous system; miR: micro RNA; MSC: mesenchymal stem cells.

\begin{tabular}{|c|c|c|c|c|c|}
\hline Administration Route & Experimental Model & Source of EVs & Therapeutic Cargo & Target Tissues & Reference \\
\hline \multirow{2}{*}{ Subcutaneous } & \multirow{2}{*}{ Mice } & AdSC & & Skin & [138] \\
\hline & & Echinostoma caproni & & Systemic immune response & [137] \\
\hline \multirow{4}{*}{ Intramuscular } & \multirow{3}{*}{ Mice } & Primary mouse satellite cells & miR-29 & Kidney, muscle & [140] \\
\hline & & Cardiac stem cells & & Muscle & [141] \\
\hline & & Human iPSCs & & Muscle & [142] \\
\hline & Chicken & Serum & & Systemic immune response & [139] \\
\hline Intrathecal & Rats & MSC & & Peripheral nerves & [148] \\
\hline Oral & Mice & Bovine milk & & Liver, spleen, heart, lungs, kidney & [144] \\
\hline Intraocular & Rabbit & MSC & & Retina & [146] \\
\hline Subconjunctival & Rabbit & MSC & & Retina & [146] \\
\hline
\end{tabular}




\section{EV Clearance}

One of the key mechanisms involved in the clearance of EVs is their uptake by the mononuclear phagocytic system. Intravenously administered EVs have shown to be rapidly cleared from blood circulation, followed by hepatic, splenic and lung accumulation [209]. Interestingly, the intravenous administration of EVs carrying an siRNA against the clathrin heavy chain reduced EV uptake by the liver and the spleen and increased accumulation in the cardiac tissue [210]. In another approach, tumor derived nanovesicles were taken up by Kupffer cells and prevented the phagocytosis of doxorubicin-loaded liposomes, which instead were efficiently delivered to the lungs [211]. Similar strategies could be used to prevent the phagocytosis of EVs loaded with therapeutic agents.

Surface proteins may also be engineered to overexpress particular surface proteins and, thus, increase EV bioavailability. For instance, cluster domain (CD) 47 is an integrin-associated transmembrane protein that protects EVs from phagocytosis and thereby increase their time of circulation. In a pancreatic ductal adenocarcinoma model, EVs with the higher expression of CD47 had a longer half-life time in circulation than particles with lower CD47 [212].

\section{Tissue Specificity}

Although several studies have shown a successful delivery of therapeutic agents via EVs (Table 2), EVs could still be engineered not only to become more invisible to the host's immune system but also to increase tissue- or cell-specificity. In fact, the accumulation of EVs at off-target sites can induce unwanted effects, thus influencing the efficacy and safety of the treatment. Coating EVs with synthetic materials or increasing the expression of certain surface proteins have been proposed as strategies to enhance the tissue specificity of the vesicles. This could ultimately lead to a more personalized treatment strategy.

PEG-coating of EVs increased the vesicle bioavailability as well as their extravasation ability, thus increasing the accumulation in tumoral tissue [213]. Kooijmans et al., [214] described the use of pegylated-targeting ligands. In particular, coating of the EVs with PEG-EGFR increased their bioavailability and enhanced the EV binding to EGFR-overexpressing tumor cells, while decreasing non-specific interactions. Similarly, coating macrophage-derived and paclitaxel loaded EVs with PEG-aminoethylanisamide, which targets the sigma receptor (usually overexpressed in lung cancer cells), was effective delivering EVs to pulmonary metastases in mice [85].

Streptavidin can be used in combination with PEG as an anchor point, and biotinylated-components (e.g., antibodies, homing peptides) targeting cells of interest can be then conjugated to the EV surface. This rather simple approach increased the uptake of EVs by cardiac fibroblasts, myoblasts and cardiomyocytes exposed to ischemic conditions, suggesting that it could be a promising strategy to increase cell-specificity not only in the heart but also in other organs [215].

Finally, the use of magnetic fields to direct EVs to a particular target has also been reported. This approach was applied to direct superparamagnetic iron oxide nanoparticle-covered EVs loaded with an experimental peptide to pancreatic islet cells to increase insulin secretion. Interestingly, the peptide loaded in the EVs showed increased plasma half-life and stronger glucose-lowering effects than the free peptide [216]. Following, the most common approaches to engineer the EV surface and thus modulate target specificity, will be discussed.

\subsection{Homing Peptides}

The display of homing peptides has been used to direct intravenously administered EVs to the CNS. Here, the cyclo(Arg-Gly-Asp-D-Tyr-Lys) peptide, which exhibits high affinity for an integrin highly expressed in ischemic brain, was added to the EV surface via click-chemistry. This strategy resulted in a significant enrichment of EVs carrying curcumin in the brain compared to non-decorated EVs [217]. A similar strategy was effective to direct EVs carrying miR-210 to ischemic brain areas [59]. Another peptide used for the same purpose is a short sequence of the rabies virus glycoprotein (RVG), 
which has been expressed in the EV-generating cells coupled to the exosomal protein Lamp2b. This resulted in the generation of EVs exhibiting a higher tropism for the central nervous system [218]. The same strategy was used to direct HEK293T EVs to the mouse brain [219]. A similar RVG peptide was used by Cui et al., [220], although by chemical coupling with dioleoylphosphatidylethanolamine $\mathrm{N}$-hydroxysuccinimide to anchor the peptide to the surface of the vesicle. Noteworthy, another study described the presence of intravenously administered EVs displaying the same RVG peptide but in muscle and kidney tissues [140]. Therefore, although this approach appears to increase the EV affinity for brain tissues, binding to other organs cannot be ruled out.

Homing peptides have also been used to direct EVs to cardiac tissue. This was reported by conjugating a cardiac homing peptide to the surface of EVs isolated from cardiac stem cells via a dioleoylphosphatidylethanolamine N-hydroxysuccinimide (DOPE-NHS) linker [121]. These decorated EVs exhibited an increased uptake of EVs by cardiomyocytes. However, the use of cardiac stem cell-derived EVs may have also contributed to this observation. Also, the decoration of EVs with another cardiac targeting peptide coupled to the EV membrane via Lamp2b increased the delivery to cardiac tissue in a mice model [221].

Peptides have also been used to increase delivery to tumor cells, such as triple negative breast cancer cells. In this case, a peptide targeting the mesenchymal-epithelial transition factor (c-Met) was conjugated to the surface of doxorubicin-loaded EVs via a 1,2-distearoyl-sn-glycero -3-phospho-ethanolamine-N-[methoxy(polyethylene glycol)-2000] link. After intravenous administration, the peptide-coated EVs exhibited a significant enrichment in the tumor tissue and displayed higher antitumor efficacy as compared to other nanoparticles or even free-doxorubicin [222]. It must be noted, however, that coated-EVs were also detected in other tissues (e.g., spleen, liver, lungs). The same principle was applied in another study where the EGFR-specific peptide GE11 was used to direct intravenously administered EVs to a mammary tumor in nude mice. Here, the coating was performed through overexpression in the EV-generating cells. A significant enrichment in the tumoral tissue was observed for GE11-EVs compared to control vesicles. Furthermore, the authors demonstrated the absence of significant damage to other organs, thus pointing towards the safety of this strategy [166]. Similarly, Tian et al., [168] demonstrated a higher antitumor efficacy of doxorubicin-loaded EVs in mice bearing MDA-MB-231 cell tumors when the EVs were coated with the iRGD peptide coupled to Lamp2b. The effect can be attributed to the specific interaction iRGD with the $\alpha \mathrm{v}$ integrin in the tumoral cells. No cardiac damage was detected. This observation could be beneficial in terms of developing therapeutic strategies to minimize the cardiotoxicity usually associated to the treatment with doxorubicin.

This strategy was also used as therapeutic alternative for glioblastoma multiforme. Both the blood-brain-barrier and glioma cells overexpress the low-density lipoprotein receptor on their surface. EVs were loaded with the anti-cancer agent methotrexate and conjugated with a peptide that targets the overexpressed lipoprotein receptor. Glioblastoma-bearing mice that were treated with these modified EVs showed a longer median survival period compared to the control groups including methotrexate alone and EVs loaded with methotrexate but without coating [178]. Noteworthy, no lesions or damage to other tissues were observed. This strategy, as an example of increased delivery to the CNS, is summarized is Figure 3.

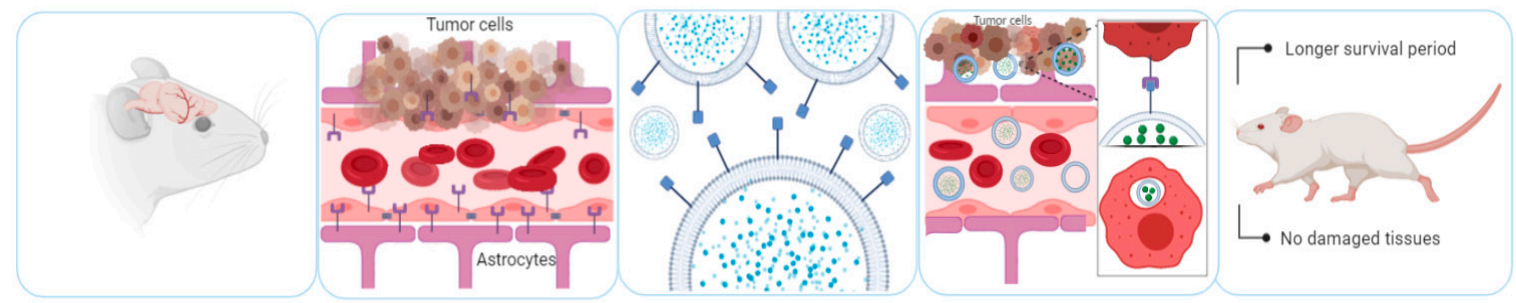

Figure 3. Engineering of the EVs to increase target specificity. Blood-brain-barrier, glia and tumor cells expressed the low-density lipoprotein (LDL) receptor. EVs loaded with methotrexate were conjugated 
with a surface peptide targeting the LDL receptor. In a mice model, administration of these modified EVs resulted in longer survival period and no damage of other tissues, as frequently observed with conventional chemotherapy strategies [178].

\subsection{Protein Ligands}

Surface proteins play a key role in the interaction between EVs and target cells. For instance, intravenous injection of EVs from cardiac progenitor stem cells overexpressing the $\mathrm{C}-\mathrm{X}-\mathrm{C}$ chemokine receptor type 4 (CXCR4) improved cardiac function in a rat model of ischemia/reperfusion injury when compared with control EVs without CXCR4 overexpression [120]. Additionally, the interaction of the integrin LFA1 on the surface of the EVs with ICAM1 on the cell surface appears to play a key role in the vesicle uptake by brain endothelial cells [177]. Also, the interaction between fibronectin on the vesicle surface and heparan sulfate on the cell surface mediates the interaction between EVs and myeloma cells [223].

Another related strategy is the addition of antibodies to the EV surface. For instance, the display of an anti-HER2 antibody on the surface of the vesicles increased the delivery of EVs to HER2 ${ }^{+}$breast cancer cells when administered intraperitoneally to mice [224]. A similar antibody-based approach was used in a mouse model of colorectal cancer where doxorubicin was delivered to tumor cells via EVs. In this case antibodies against the A33 antigen were used. Noteworthy, the antibodies were not added directly to the surface of the EVs but to superparamagnetic iron nanoparticles, thus allowing a magnetically-directed delivery to the tumor region while increasing also the specificity for tumor cells. Again, no cardiac damage was observed, as compared to the strategies without A33 antibody addition or to free doxorubicin [52]. Similarly, intravenous administration of EVs displaying an HIV-1 specific monoclonal antibody and loaded with curcumin resulted in a higher growth inhibition of solid tumors expressing the HIV-1 envelope protein (Env) in mice. Since most HIV-1 infected cells display viral proteins on their surface, this strategy bears an enormous potential for precision HIV antiviral therapy [164].

\subsection{Nucleic Acids}

DNA and RNA molecules displayed on the cell surface may also be used to increase target specificity. For instance, a DNA aptamer displayed on EVs from bone marrow stromal cells was used to enhance the delivery of EVs to the bone in mice which received EVs intravenously [163]. Synthetic RNA nanoparticles can be added to the surface of the EVs as a platform to incorporate further tissue-specific ligands. This was described for folic acid. When the EVs were loaded with a therapeutic siRNA against survivin, coupling to folic acid resulted in a higher inhibition of the tumor growth in a mice xenograft model for human epidermoid carcinoma, as compared with vesicles without folic acid on their surface. The increased specificity could be explained based on the interaction between folic acid on the EV surface and the folate receptor in the tumor cells [42].

\subsection{EV-Surface Glycosylation}

The glycosylation of surface proteins plays an important role in EV-cell interaction. It was described that the treatment of EVs with neuraminidase, which removes the terminal sialic acid residues of surface proteins, affects the distribution of EVs after administration to mice. A higher enrichment in the lungs was observed when neuraminidase-treated EVs were administered intravenously respect to the untreated EVs. Similarly, when neuraminidase-treated EVs were administered into the hock, the distribution among the lymph nodes displayed a different pattern respect to untreated EVs [225].

A different strategy is modifying the surface of the EVs with cationized pullulan, a polysaccharide that consists of maltotriose-units. Tamura et al., [226] used cationized pullulan to enhance the electrostatic interaction and uptake of EVs by liver cells. After administering pullulan-modified EVs to a mouse model of liver injury, there was an improved anti-inflammatory and tissue-regenerative effect in comparison with the original vesicles. The effects could be explained in terms of the interaction 
between pullulan and asialoglycoprotein [226]. Similarly, decoration of doxorubicin-loaded EVs with hyaluronan-PEG resulted in a differential uptake of the vesicles to breast cancer and lung adenocarcinoma cells in vitro. Notably, the vesicle-based strategy led to a higher inhibition of cell growth respect to the treatment with free doxorubicin. These findings could be explained at the molecular level due to the interaction between hyaluronan and CD44, overexpressed in the surface of cancer cells [227]. Similarly, serum-derived exosomes incorporating mannose-conjugated PEG-1,2-distearoyl-sn-glycero-3-phosphoethanolamine in their lipid bilayer showed high accumulation in mannose-receptor expressing dendritic cells and lymph nodes [228].

\section{Clinical Grade Production}

Translation of the previously described findings, mostly obtained in experimentation animals, to the clinical practice requires standardized good manufacturing practices (GMPs). Several challenges arise at all the steps of the production and have been recently reviewed by Wiest et al., [229]. The selection of the cellular sources and the characterization of the vesicles represent one of the first challenges. Here, adhering to the position paper of the ISEV on the minimal information for studies of extracellular vesicles 2018 (MISEV 2018) should be the starting point for defining production strategies [5]. Furthermore, clinical grade production requires adherence to strict quality and safety regulations. Hereby, the International Council for Harmonisation of Technical Requirements for Pharmaceuticals for Human Use (ICH) develops guidelines on quality, safety and efficacy. Regarding regulatory requirements for EV based therapeutics, considering the complexity and challenges associated with EVs, a case by case regulatory approach seems more plausible for the evaluation of EVs as DDS rather than an all-purpose approach. Currently there are no specific regulatory guidelines for EVs, although they have to be filed and regulated as drugs and biological products according to the Food and Drug Administration (FDA), depending on the origin, isolation procedure, route of administration, active substance, or mechanism of action, and are subjected to premarket review and approval. Further discussion on the regulatory challenges to perform clinical trials using EVs can be found in a recent position paper from the ISEV [230] and have been reviewed elsewhere [231].

So far, only a few studies described the production and characterization of clinical-grade EVs following GMPs. Previously, Kamerkar et al., [212] highlighted the potential of EVs loaded with an siRNA against the mutated form of the RAS kinase. In a more recent study of the same group, the generation of clinical-grade EVs following GMPs from the selection of the donor to the isolation and loading was presented [232]. Here, the authors not only succeeded in the upscaling of the loading electroporation protocol to higher sample volumes but also demonstrated the efficacy of the preparation in a mouse-model. Also, importantly, the authors confirmed the stability of the EVs (i.e., number and size distribution) after freezing at $-80^{\circ} \mathrm{C}$ for 45 days or 6 months. Storage at room temperature or 4 ${ }^{\circ} \mathrm{C}$ for 2 or more days resulted in a decrease in the therapeutic efficacy assessed in vitro. The successful design and validation of this strategy led to the register of a clinical trial (NCT03608631, see Section 7). The replacement of animal materials in the production process is an important requirement for clinical grade EVs. In this regard, FCS can be replaced by human platelet lysates depleted of EVs [233].

Production of large volumes of high purity EVs is an important challenge. Here, a combination of tangential flow filtration (TFF) and size exclusion chromatography (SEC) exhibited significant advantages respect to other isolation methods [234]. EVs carrying the heterodimeric interleukin-15 were isolated from HEK293 cells cultured in hollow fiber bioreactors. The combination of both isolation techniques resulted in a lower contamination with proteins without decreasing the yield. Similarly, a comparative study between TFF and ultracentrifugation highlighted the higher batch-to-batch reproducibility in the size distribution of EVs isolated by TFF. Moreover, removal of protein contaminants was not only 40 times higher using TFF but also exhibited less variability than ultracentrifugation. Noteworthy, EV suspensions obtained by TFF also tested negative for mycoplasma, bacteria and endotoxin [235]. The successful use of TFF for the production of EVs from bone marrow 
MSCs and ASCs was also reported [236,237]. Altogether, TFF appears as a useful tool in terms of obtaining high purity clinical grade EV suspensions with high reproducibility between batches.

The previous studies established production pipelines for clinical grade EVs and provide a proof-of-concept on the feasibility of different processes. Other studies described extensive quality controls (QCs) that would be required for industrial production. For instance, the study of Andriolo et al., describing GMP-compliant EV production from cardiac progenitor cells, described exhaustive QC tests. First, the stability of the cell source was controlled by establishing a post-production cell bank (i.e., cells at the limit of the time, in which they are suitable for production) only for QC purposes. Comparisons between this cell bank and the master cell bank using in the regular production constitute an important QC. Furthermore, the authors perform an extensive QC on two batches of EVs in terms of sterility, presence of endotoxin, particle concentration and size, expression of exosome markers and total protein. Also, functional checks (e.g., proangiogenic activity) displaying comparable results with both lots of EVs were presented [238]. Likewise, another study analyzed the batch-to-batch variability of EVs obtained from ASCs through TFF. High reproducibility was registered in terms of size and surface markers and purity [239].

Hitherto, a wide variety of vesicles have been used to target different tissues and organs in experimentation animals. However, only a few of these vesicle types have been validated for clinical grade production. One critical aspect that needs special attention is, besides those presented above, the effect of interindividual variability of the cell donors on the batch-to-batch variability of the produced EVs. In addition, while GMP-grade culture media and supplements and TFF-mediated isolation led to the production and validation of different EV suspensions, it is yet unclear whether this constitutes a cost-effective alternative. Finally, more comparative studies addressing the impact of the different strategies for the preparation and storage of clinical grade EV formulations on their safety and potency are also required.

\section{Clinical Trials}

Different high-quality studies performed in animal models support the potential of EVs as a DDS from the point of view of the safety and efficacy at the preclinical level. At the clinical level, the application of EVs is still at a very early stage. So far, 18 clinical trials involving therapeutic use of EVs have been registered at the NIH website [240] (Table 3). Noteworthy, two studies evaluate the use of EVs as DDS. In particular, the study NCT01294072 plans to evaluate the use of plant-derived EVs for curcumin delivery to normal and colon cancer, while the NCT03608631 study plans to evaluate the delivery of a therapeutic siRNA to pancreas cancer tissue. Although the rest of the studies do not foresee the use of vesicles as drug carriers, they could provide information concerning the tolerability of EV administration, suitability of different administration routes (e.g., topical, intravenous, oral, inhalation) and use of different sources of EVs (plasma, plants, MSCs, adipose tissue stem cells). Although no results of the current studies are yet available, this information may later be used towards optimizing the use of EVs for delivering therapeutic agents in clinical practice. 
Table 3. Clinical trials registered at clinicaltrials.gov using EVs for therapeutic purposes. Studies using EVs as a drug delivery system are highlighted in bold. Abbreviations: AdSCs: adipose tissue stem cells; MSCs: mesenchymal stem cells; SARS-CoV-2: several acute respiratory syndrome coronavirus 2.

\begin{tabular}{|c|c|c|c|}
\hline EVs & Disease or Condition & Route of Administration & NCT Number \\
\hline Plant EVs loaded with curcumin & Colon cancer & Oral & NCT01294072 \\
\hline MSCs EVs loaded with KRAS G12D siRNA & Pancreas cancer & Intravenous & NCT03608631 \\
\hline MSCs & Healthy individuals & Inhalation & NCT04313647 \\
\hline MSCs & SARS-CoV-2 & Inhalation & NCT04276987 \\
\hline MSCs & Acute ischemic stroke & Stereotaxic injection & NCT03384433 \\
\hline MSCs & Macular holes & Intravitreous injection & NCT03437759 \\
\hline MSCs & Dystrophic epidermolysis bullosa & Topical & NCT04173650 \\
\hline MSCs & Depression, anxiety, neurodegenerative disorders & Intravenous & NCT04202770 \\
\hline MSCs & Bronchopulmonary dysplasia & Intravenous & NCT03857841 \\
\hline MSCs & Type 1 diabetes mellitus & Intravenous & NCT02138331 \\
\hline MSCs & SARS-CoV-2 & Inhalation & NCT04491240 \\
\hline MSCs & Alzheimer disease & Intranasal & NCT04388982 \\
\hline MSCs & SARS-CoV-2 & Intravenous & NCT04493242 \\
\hline AdSCs & Periodontitis & Local injection & NCT04270006 \\
\hline Plasma & Cutaneous wounds & Topical & NCT02565264 \\
\hline Not specified & Craniofacial neuralgia & Epineural injection, intravenous & NCT04202783 \\
\hline Not specified & Acute myocardial infarction & Intracoronary & NCT04327635 \\
\hline Plant & $\begin{array}{l}\text { Oral mucositis associated } \\
\text { with chemoradiotherapy }\end{array}$ & Topical & NCT01668849 \\
\hline
\end{tabular}




\section{Future Perspectives and Conclusions}

In the last ten years, the understanding of the role of EVs in cell communication and their potential as a source of biomarkers have been acknowledged and further explored. More recently, there has been an increase in the body of evidence addressing EV secretion, biodistribution and specificity. These findings point to a significant potential of EVs to be used as a DDS. This novel delivery strategy shows high promise, although many questions remain unanswered regarding EVs, along with technical and experimental challenges that hinder the translation from the laboratory to clinical trials.

One still remaining challenge is assuring the safety of EV-based treatments. Although several studies in animal models indicate a high tolerability and ongoing clinical trials will evaluate this in humans, further research should be performed to rule out potential deleterious effects of the carrier EVs in cell-cell communication. Hereby, the use of plant EVs may have an advantage by carrying a natural cargo less related to human EVs. While the delivery potential would still be present, the chance of triggering physiological or pathophysiological responses (e.g., immune response) may be lower.

Another challenge regarding EV research, is target specificity. So far, several engineering possibilities have been evaluated. Unfortunately, while many studies nicely describe an increased targeting of certain organs and tissues, off-target delivery is not always evaluated. Furthermore, future research regarding surface molecules mediating the interaction between EVs and target cells will contribute towards increasing the delivery specificity for EVs. Hereby, the characterization of the surface proteome of the EVs and the surface glycan profile of target cells could significantly improve EV target specificity.

In summary, the design of therapeutic strategies using EVs as a DDS will require the optimization of all the steps of involved in the EV pipeline. Safe and efficient sources of EVs, along with isolation and loading techniques that are cost-efficient and allow to scale production, in combination with the validation of proper administration routes and EVs that are specific for a particular target, remain the cornerstone in EV research. In this way, EVs could be proposed as a new alternative in precision medicine, aimed at increasing therapeutic efficacy and decreasing side effects, resulting in improved quality of life for the patients.

Author Contributions: Conceptualization, J.P.R.; writing-original draft preparation, B.d.J., E.R.B., J.P.R.; writing-review and editing, B.d.J., E.R.B., J.G.J.H., J.P.R.; visualization, B.d.J.; supervision, J.G.J.H., J.P.R.; funding acquisition, E.R.B., J.G.J.H., J.P.R. All authors have read and agreed to the published version of the manuscript.

Funding: This research is funded by the Netherlands Organisation for Scientific Research (NWO, VICI 016.130.668). Juan Pablo Rigalli is a fellow of the Radboud Excellence Initiative (Radboud University, Nijmegen, the Netherlands). Eric Barros holds CONICYT-PhD (Chile) and Faculty of Medicine, Pontificia Universidad Católica de Chile (PUC) PhD fellowships.

Acknowledgments: Figures were created using BioRender.com.

Conflicts of Interest: The authors declare no conflict of interest. The funders had no role in the design of the study; in the collection, analyses, or interpretation of data; in the writing of the manuscript, or in the decision to publish the results.

\section{References}

1. Rigalli, J.P.; Tocchetti, G.N.; Weiss, J. Modulation of ABC transporters by nuclear receptors: Physiological, pathological and pharmacological aspects. Curr. Med. Chem. 2019, 26, 1079-1112. [CrossRef]

2. Arana, M.R.; Tocchetti, G.N.; Rigalli, J.P.; Mottino, A.D.; Villanueva, S.S. Physiological and pathophysiological factors affecting the expression and activity of the drug transporter MRP2 in intestine. Impact on its function as membrane barrier. Pharmacol. Res. 2016, 109, 32-44. [CrossRef] [PubMed]

3. Tkach, M.; Théry, C. Communication by extracellular vesicles: Where we are and where we need to go. Cell 2016, 164, 1226-1232. [CrossRef] [PubMed]

4. D'Souza-Schorey, C.; Schorey, J.S. Regulation and mechanisms of extracellular vesicle biogenesis and secretion. Essays Biochem. 2018, 62, 125-133. [CrossRef] 
5. Théry, C.; Witwer, K.W.; Aikawa, E.; Alcaraz, M.J.; Anderson, J.D.; Andriantsitohaina, R.; Antoniou, A.; Arab, T.; Archer, F.; Atkin-Smith, G.K.; et al. Minimal information for studies of extracellular vesicles 2018 (MISEV2018): A position statement of the International Society for Extracellular Vesicles and update of the MISEV2014 guidelines. J. Extracell. Vesicles 2018, 23, 1535750. [CrossRef] [PubMed]

6. Yamamoto, T.; Kosaka, N.; Ochiya, T. Latest advances in extracellular vesicles: From bench to bedside. Sci. Technol. Adv. Mater. 2019, 20, 746-757. [CrossRef] [PubMed]

7. Maacha, S.; Bhat, A.A.; Jimenez, L.; Raza, A.; Haris, M.; Uddin, S.; Grivel, J.C. Extracellular vesicles-mediated intercellular communication: Roles in the tumor microenvironment and anti-cancer drug resistance. Mol. Cancer 2019, 18, 55. [CrossRef] [PubMed]

8. Simeone, P.; Bologna, G.; Lanuti, P.; Pierdomenico, L.; Guagnano, M.T.; Pieragostino, D.; Del Boccio, P.; Vergara, D.; Marchisio, M.; Miscia, S. Extracellular vesicles as signaling mediators and disease biomarkers across biological barriers. Int. J. Mol. Sci. 2020, 21, 2514. [CrossRef]

9. Fröhlich, E. The role of surface charge in cellular uptake and cytotoxicity of medical nanoparticles. Int. J. Nanomed. 2012, 7, 5577-5591. [CrossRef]

10. Wolfram, J.; Ferrari, M. Clinical cancer nanomedicine. Nano Today 2019, 25, 85-98. [CrossRef]

11. Zhu, X.; Badawi, M.; Pomeroy, S.; Sutaria, D.S.; Xie, Z.; Baek, A.; Jiang, J.; Elgamal, O.A.; Mo, X.; Perle, K.; et al. Comprehensive toxicity and immunogenicity studies reveal minimal effects in mice following sustained dosing of extracellular vesicles derived from HEK293T cells. J. Extracell. Vesicles 2017, 6, 1324730. [CrossRef] [PubMed]

12. Muntasell, A.; Berger, A.C.; Roche, P.A. T cell-induced secretion of MHC class II-peptide complexes on B cell exosomes. EMBO J. 2007, 26, 4263-4272. [CrossRef] [PubMed]

13. Nolte-'t Hoen, E.N.; Buschow, S.I.; Anderton, S.M.; Stoorvogel, W.; Wauben, M.H. Activated T cells recruit exosomes secreted by dendritic cells via LFA-1. Blood 2009, 113, 1977-1981. [CrossRef] [PubMed]

14. Zitvogel, L.; Regnault, A.; Lozier, A.; Wolfers, J.; Flament, C.; Tenza, D.; Ricciardi-Castagnoli, P.; Raposo, G.; Amigorena, S. Eradication of established murine tumors using a novel cell-free vaccine: Dendritic cell-derived exosomes. Nat. Med. 1998, 4, 594-600. [CrossRef] [PubMed]

15. Vincent-Schneider, H.; Stumptner-Cuvelette, P.; Lankar, D.; Pain, S.; Raposo, G.; Benaroch, P.; Bonnerot, C. Exosomes bearing HLA-DR1 molecules need dendritic cells to efficiently stimulate specific $\mathrm{T}$ cells. Int. Immunol. 2002, 14, 713-722. [CrossRef]

16. Théry, C.; Duban, L.; Segura, E.; Véron, P.; Lantz, O.; Amigorena, S. Indirect activation of naïve CD4+ T cells by dendritic cell-derived exosomes. Nat. Immunol. 2002, 3, 1156-1162. [CrossRef]

17. Sukhikh, G.T.; Pekarev, O.G.; Maiborodin, I.V.; Silachev, D.N.; Shevtsova, Y.A.; Goryunov, K.V.; Onoprienko, N.V.; Maiborodina, V.I.; Galenok, R.V.; Novikov, A.V.; et al. Preservation of mesenchymal stem cell-derived extracellular vesicles after abdominal delivery in the experiment. Bull. Exp. Biol. Med. 2020, 169, 122-129. [CrossRef]

18. Lee, C.; Mitsialis, S.A.; Aslam, M.; Vitali, S.H.; Vergadi, E.; Konstantinou, G.; Sdrimas, K.; Fernandez-Gonzalez, A.; Kourembanas, S. Exosomes mediate the cytoprotective action of mesenchymal stromal cells on hypoxia-induced pulmonary hypertension. Circulation 2012, 126, 2601-2611. [CrossRef]

19. Pang, X.L.; Wang, Z.G.; Liu, L.; Feng, Y.H.; Wang, J.X.; Xie, H.C.; Yang, X.L.; Li, J.F.; Feng, G.W. Immature dendritic cells derived exosomes promotes immune tolerance by regulating $\mathrm{T}$ cell differentiation in renal transplantation. Aging 2019, 26, 8911-8924. [CrossRef] [PubMed]

20. Haney, M.J.; Zhao, Y.; Jin, Y.S.; Li, S.M.; Bago, J.R.; Klyachko, N.L.; Kabanov, A.V.; Batrakova, E.V. Macrophage-derived extracellular vesicles as drug delivery systems for triple negative breast cancer (TNBC) therapy. J. Neuroimmune Pharmacol. 2020, 15, 487-500. [CrossRef]

21. Zheng, H.C. The molecular mechanisms of chemoresistance in cancers. Oncotarget 2017, 8, 59950-59964. [CrossRef]

22. Kim, S.M.; Yang, Y.; Oh, S.J.; Hong, Y.; Seo, M.; Jang, M. Cancer-derived exosomes as a delivery platform of CRISPR/Cas9 confer cancer cell tropism-dependent targeting. J. Control. Release 2017, 266, 8-16. [CrossRef] [PubMed]

23. Garofalo, M.; Villa, A.; Crescenti, D.; Marzagalli, M.; Kuryk, L.; Limonta, P.; Mazzaferro, V.; Ciana, P. Heterologous and cross-species tropism of cancer-derived extracellular vesicles. Theranostics 2019, 9, 5681-5693. [CrossRef] 
24. Burgio, S.; Noori, L.; Marino Gammazza, A.; Campanella, C.; Logozzi, M.; Fais, S.; Bucchieri, F.; Cappello, F.; Caruso Bavisotto, C. Extracellular vesicles-based drug delivery systems: A new challenge and the exemplum of malignant pleural mesothelioma. Int. J. Mol. Sci. 2020, 21, 5432. [CrossRef] [PubMed]

25. Rohde, E.; Pachler, K.; Gimona, M. Manufacturing and characterization of extracellular vesicles from umbilical cord-derived mesenchymal stromal cells for clinical testing. Cytotherapy 2019, 21, 581-592. [CrossRef] [PubMed]

26. Liang, Q.; Bie, N.; Yong, T.; Tang, K.; Shi, X.; Wei, Z.; Jia, H.; Zhang, X.; Zhao, H.; Huang, W.; et al. The softness of tumour-cell-derived microparticles regulates their drug-delivery efficiency. Nat. Biomed. Eng. 2019, 3, 729-740. [CrossRef] [PubMed]

27. Shiri, F.; Gale, B.K.; Sant, H.; Bardi, G.T.; Hood, J.L.; Petersen, K.E. Characterization of human glioblastoma versus normal plasma-derived extracellular vesicles preisolated by differential centrifugation using cyclical electrical field-flow fractionation. Anal. Chem. 2020, 92, 9866-9876. [CrossRef] [PubMed]

28. Kamyabi, N.; Abbasgholizadeh, R.; Maitra, A.; Ardekani, A.; Biswal, S.L.; Grande-Allen, K.J. Isolation and mutational assessment of pancreatic cancer extracellular vesicles using a microfluidic platform. Biomed. Microdevices 2020, 22, 23. [CrossRef]

29. Lennon, K.M.; Wakefield, D.L.; Maddox, A.L.; Brehove, M.S.; Willner, A.N.; Garcia-Mansfield, K.; Meechoovet, B.; Reiman, R.; Hutchins, E.; Miller, M.M.; et al. Single molecule characterization of individual extracellular vesicles from pancreatic cancer. J. Extracell. Vesicles 2019, 8, 1685634. [CrossRef]

30. Shin, H.; Park, Y.H.; Kim, Y.G.; Lee, J.Y.; Park, J. Aqueous two-phase system to isolate extracellular vesicles from urine for prostate cancer diagnosis. PLOS ONE 2018, 13, e0194818. [CrossRef]

31. Liang, L.G.; Sheng, Y.F.; Zhou, S.; Inci, F.; Li, L.; Demirci, U.; Wang, S. An integrated double-filtration microfluidic device for detection of extracellular vesicles from urine for bladder cancer diagnosis. Methods Mol. Biol. 2017, 1660, 355-364. [CrossRef]

32. Kagota, S.; Taniguchi, K.; Lee, S.W.; Ito, Y.; Kuranaga, Y.; Hashiguchi, Y.; Inomata, Y.; Imai, Y.; Tanaka, R.; Tashiro, K.; et al. Analysis of extracellular vesicles in gastric juice from gastric cancer patients. Int. J. Mol. Sci. 2019, 20, 953. [CrossRef]

33. Ludwig, N.; Hong, C.S.; Ludwig, S.; Azambuja, J.H.; Sharma, P.; Theodoraki, M.N.; Whiteside, T.L. Isolation and analysis of tumor-derived exosomes. Curr. Protoc. Immunol. 2019, 127, e91. [CrossRef] [PubMed]

34. Pomatto, M.A.C.; Bussolati, B.; D'Antico, S.; Ghiotto, S.; Tetta, C.; Brizzi, M.F.; Camussi, G. Improved loading of plasma-derived extracellular vesicles to encapsulate antitumor miRNAs. Mol. Ther. Methods Clin. Dev. 2019, 13, 133-144. [CrossRef] [PubMed]

35. Vázquez-Ríos, A.J.; Molina-Crespo, Á.; Bouzo, B.L.; López-López, R.; Moreno-Bueno, G.; de la Fuente, M. Exosome-mimetic nanoplatforms for targeted cancer drug delivery. J. Nanobiotechnol. 2019, 17, 85. [CrossRef] [PubMed]

36. Qu, M.; Lin, Q.; Huang, L.; Fu, Y.; Wang, L.; He, S.; Fu, Y.; Yang, S.; Zhang, Z.; Zhang, L.; et al. Dopamine-loaded blood exosomes targeted to brain for better treatment of Parkinson's disease. J. Control Release 2018, 287, 156-166. [CrossRef]

37. Yu, G.; Jung, H.; Kang, Y.Y.; Mok, H. Comparative evaluation of cell- and serum-derived exosomes to deliver immune stimulators to lymph nodes. Biomaterials 2018, 162, 71-81. [CrossRef]

38. Sun, I.O.; Lerman, L.O. Urinary extracellular vesicles as biomarkers of kidney disease: From diagnostics to therapeutics. Diagnostics 2020, 10, 311. [CrossRef]

39. Nakamichi, E.; Sakakura, H.; Mii, S.; Yamamoto, N.; Hibi, H.; Asai, M.; Takahashi, M. Detection of serum/salivary exosomal Alix in patients with oral squamous cell carcinoma. Oral Dis. 2020, in press. [CrossRef]

40. Ling, X.; Zhang, G.; Xia, Y.; Zhu, Q.; Zhang, J.; Li, Q.; Niu, X.; Hu, G.; Yang, Y.; Wang, Y.; et al. Exosomes from human urine-derived stem cells enhanced neurogenesis via miR-26a/HDAC6 axis after ischaemic stroke. J. Cell Mol. Med. 2020, 24, 640-654. [CrossRef]

41. Munagala, R.; Aqil, F.; Jeyabalan, J.; Gupta, R.C. Bovine milk-derived exosomes for drug delivery. Cancer Lett. 2016, 371, 48-61. [CrossRef] [PubMed]

42. Li, Z.; Wang, H.; Yin, H.; Bennett, C.; Zhang, H.G.; Guo, P. Arrowtail RNA for ligand display on ginger exosome-like nanovesicles to systemic deliver siRNA for cancer suppression. Sci. Rep. 2018, 8, 14644. [CrossRef] [PubMed] 
43. Gandham, S.; Su, X.; Wood, J.; Nocera, A.L.; Alli, S.C.; Milane, L.; Zimmerman, A.; Amiji, M.; Ivanov, A.R. Technologies and standardization in research on extracellular vesicles. Trends Biotechnol. 2020, 38, 1066-1098. [CrossRef] [PubMed]

44. Laulagnier, K.; Vincent-Schneider, H.; Hamdi, S.; Subra, C.; Lankar, D.; Record, M. Characterization of exosome subpopulations from RBL-2H3 cells using fluorescent lipids. Blood Cells Mol. Dis. 2005, 35, 116-121. [CrossRef]

45. Smith, J.A.; Leonardi, T.; Huang, B.; Iraci, N.; Vega, B.; Pluchino, S. Extracellular vesicles and their synthetic analogues in aging and age-associated brain diseases. Biogerontology 2015, 16, 147-185. [CrossRef]

46. Shin, H.; Han, C.; Labuz, J.M.; Kim, J.; Kim, J.; Cho, S.; Gho, Y.S.; Takayama, S.; Park, J. High-yield isolation of extracellular vesicles using aqueous two-phase system. Sci. Rep. 2015, 14. [CrossRef]

47. Yuan, Z.; Kolluri, K.K.; Gowers, K.H.; Janes, S.M. TRAIL delivery by MSC-derived extracellular vesicles is an effective anticancer therapy. J. Extracell. Vesicles 2017, 6, 1265291. [CrossRef]

48. Yim, N.; Ryu, S.W.; Choi, K.; Lee, K.R.; Lee, S.; Choi, H.; Kim, J.; Shaker, M.R.; Sun, W.; Park, J.H.; et al. Exosome engineering for efficient intracellular delivery of soluble proteins using optically reversible protein-protein interaction module. Nat. Commun. 2016, 7, 12277. [CrossRef]

49. Zheng, M.; Huang, J.; Tong, A.; Yang, H. Oncolytic viruses for cancer therapy: Barriers and recent advances. Mol. Ther. Oncolytics 2019, 15, 234-247. [CrossRef]

50. Gould, S.J.; Booth, A.M.; Hildreth, J.E. The Trojan exosome hypothesis. Proc. Natl. Acad. Sci. USA 2003, 100, 10592-10597. [CrossRef]

51. Garofalo, M.; Saari, H.; Somersalo, P.; Crescenti, D.; Kuryk, L.; Aksela, L.; Capasso, C.; Madetoja, M.; Koskinen, K.; Oksanen, T.; et al. Antitumor effect of oncolytic virus and paclitaxel encapsulated in extracellular vesicles for lung cancer treatment. J. Control. Release 2018, 283, 223-234. [CrossRef]

52. Li, Y.; Gao, Y.; Gong, C.; Wang, Z.; Xia, Q.; Gu, F.; Hu, C.; Zhang, L.; Guo, H.; Gao, S. A33 antibody-functionalized exosomes for targeted delivery of doxorubicin against colorectal cancer. Nanomedicine 2018, 14, 1973-1985. [CrossRef] [PubMed]

53. Kalinec, G.M.; Gao, L.; Cohn, W.; Whitelegge, J.P.; Faull, K.F.; Kalinec, F. Extracellular vesicles from auditory cells as nanocarriers for anti-inflammatory drugs and pro-resolving mediators. Front Cell Neurosci. 2019, 13, 530. [CrossRef] [PubMed]

54. Kalinec, G.M.; Cohn, W.; Whitelegge, J.P.; Faull, K.F.; Kalinec, F. Preliminary characterization of extracellular vesicles from auditory HEI-OC1 cells. Ann. Otol. Rhinol. Laryngol. 2019, 128, S52-S60. [CrossRef] [PubMed]

55. Lamichhane, T.N.; Jay, S.M. Production of extracellular vesicles loaded with therapeutic cargo. Methods Mol. Biol. 2018, 1831, 37-47. [CrossRef]

56. Saari, H.; Lázaro-Ibáñez, E.; Viitala, T.; Vuorimaa-Laukkanen, E.; Siljander, P.; Yliperttula, M. Microvesicleand exosome-mediated drug delivery enhances the cytotoxicity of Paclitaxel in autologous prostate cancer cells. J. Control. Release 2015, 220, 727-737. [CrossRef] [PubMed]

57. Fuhrmann, G.; Serio, A.; Mazo, M.; Nair, R.; Stevens, M.M. Active loading into extracellular vesicles significantly improves the cellular uptake and photodynamic effect of porphyrins. J. Control. Release 2015, 205, 35-44. [CrossRef]

58. Wei, H.; Chen, J.; Wang, S.; Fu, F.; Zhu, X.; Wu, C.; Liu, Z.; Zhong, G.; Lin, J. A nanodrug consisting of doxorubicin and exosome derived from mesenchymal stem cells for osteosarcoma treatment in vitro. Int. J. Nanomed. 2019, 14, 8603-8610. [CrossRef]

59. Zhang, H.; Wu, J.; Wu, J.; Fan, Q.; Zhou, J.; Wu, J.; Liu, S.; Zang, J.; Ye, J.; Xiao, M.; et al. Exosome-mediated targeted delivery of miR-210 for angiogenic therapy after cerebral ischemia in mice. J. Nanobiotechnol. 2019, 17, 29. [CrossRef]

60. Perteghella, S.; Crivelli, B.; Catenacci, L.; Sorrenti, M.; Bruni, G.; Necchi, V.; Vigani, B.; Sorlini, M.; Torre, M.L.; Chlapanidas, T. Stem cell-extracellular vesicles as drug delivery systems: New frontiers for silk/curcumin nanoparticles. Int. J. Pharm. 2017, 520, 86-97. [CrossRef]

61. O’Loughlin, A.J.; Mäger, I.; De Jong, O.G.; Varela, M.A.; Schiffelers, R.M.; El Andaloussi, S.; Wood, M.J.A.; Vader, P. Functional delivery of lipid-conjugated siRNA by extracellular vesicles. Mol. Ther. 2017, 25, 1580-1587. [CrossRef] [PubMed]

62. Yang, X.; Shi, G.; Guo, J.; Wang, C.; He, Y. Exosome-encapsulated antibiotic against intracellular infections of methicillin-resistant Staphylococcus aureus. Int. J. Nanomed. 2018, 13, 8095-8104. [CrossRef] [PubMed] 
63. Kim, M.S.; Haney, M.J.; Zhao, Y.; Mahajan, V.; Deygen, I.; Klyachko, N.L.; Inskoe, E.; Piroyan, A.; Sokolsky, M.; Okolie, O.; et al. Development of exosome-encapsulated paclitaxel to overcome MDR in cancer cells. Nanomedicine 2016, 12, 655-664. [CrossRef] [PubMed]

64. Haney, M.J.; Klyachko, N.L.; Zhao, Y.; Gupta, R.; Plotnikova, E.G.; He, Z.; Patel, T.; Piroyan, A.; Sokolsky, M.; Kabanov, A.V.; et al. Exosomes as drug delivery vehicles for Parkinson's disease therapy. J. Control. Release 2015, 207, 18-30. [CrossRef] [PubMed]

65. Silva, A.K.; Ménager, C.; Wilhelm, C. Magnetic drug carriers: Bright insights from light-responsive magnetic liposomes. Nanomedicine 2015, 10, 2797-2799. [CrossRef]

66. Salarpour, S.; Forootanfar, H.; Pournamdari, M.; Ahmadi-Zeidabadi, M.; Esmaeeli, M.; Pardakhty, A. Paclitaxel incorporated exosomes derived from glioblastoma cells: Comparative study of two loading techniques. Daru 2019, 27, 533-539. [CrossRef]

67. Wu, Y.W.; Huang, C.C.; Changou, C.A.; Lu, L.S.; Goubran, H.; Burnouf, T. Clinical-grade cryopreserved doxorubicin-loaded platelets: Role of cancer cells and platelet extracellular vesicles activation loop. J. Biomed. Sci. 2020, 27, 45. [CrossRef]

68. Carobolante, G.; Mantaj, J.; Ferrari, E.; Vllasaliu, D. Cow Milk and intestinal epithelial cell-derived extracellular vesicles as systems for enhancing oral drug delivery. Pharmaceutics 2020, 12, 226. [CrossRef]

69. Wang, Y.; Chen, X.; Tian, B.; Liu, J.; Yang, L.; Zeng, L.; Chen, T.; Hong, A.; Wang, X. Nucleolin-targeted extracellular vesicles as a versatile platform for biologics delivery to breast cancer. Theranostics 2017, 7, 1360-1372. [CrossRef]

70. Martins-Marques, T.; Pinho, M.J.; Zuzarte, M.; Oliveira, C.; Pereira, P.; Sluijter, J.P.; Gomes, C.; Girao, H. Presence of $\mathrm{Cx} 43$ in extracellular vesicles reduces the cardiotoxicity of the anti-tumour therapeutic approach with doxorubicin. J. Extracell. Vesicles 2016, 5, 32538. [CrossRef]

71. Limoni, S.K.; Moghadam, M.F.; Moazzeni, S.M.; Gomari, H.; Salimi, F. Engineered exosomes for targeted transfer of siRNA to HER2 positive breast cancer cells. Appl. Biochem. Biotechnol. 2019, 187, 352-364. [CrossRef] [PubMed]

72. Faruqu, F.N.; Xu, L.; Al-Jamal, K.T. Preparation of exosomes for siRNA delivery to cancer cells. J. Vis. Exp. 2018, 142, e58814. [CrossRef]

73. Schindler, C.; Collinson, A.; Matthews, C.; Pointon, A.; Jenkinson, L.; Minter, R.R.; Vaughan, T.J.; Tigue, N.J. Exosomal delivery of doxorubicin enables rapid cell entry and enhanced in vitro potency. PLoS ONE 2019, 14, e0214545. [CrossRef] [PubMed]

74. Lamichhane, T.N.; Raiker, R.S.; Jay, S.M. Exogenous DNA loading into extracellular vesicles via electroporation is size-dependent and enables limited gene delivery. Mol. Pharm. 2015, 12, 3650-3657. [CrossRef] [PubMed]

75. Jung, K.O.; Jo, H.; Yu, J.H.; Gambhir, S.S.; Pratx, G. Development and MPI tracking of novel hypoxia-targeted theranostic exosomes. Biomaterials 2018, 177, 139-148. [CrossRef] [PubMed]

76. Gomari, H.; Forouzandeh Moghadam, M.; Soleimani, M.; Ghavami, M.; Khodashenas, S. Targeted delivery of doxorubicin to HER2 positive tumor models. Int. J. Nanomed. 2019, 14, 5679-5690. [CrossRef] [PubMed]

77. Liu, T.; Zhang, X.; Du, L.; Wang, Y.; Liu, X.; Tian, H.; Wang, L.; Li, P.; Zhao, Y.; Duan, W.; et al. Exosome-transmitted miR-128-3p increase chemosensitivity of oxaliplatin-resistant colorectal cancer. Mol. Cancer 2019, 18, 43. [CrossRef] [PubMed]

78. Jia, G.; Han, Y.; An, Y.; Ding, Y.; He, C.; Wang, X.; Tang, Q. NRP-1 targeted and cargo-loaded exosomes facilitate simultaneous imaging and therapy of glioma in vitro and in vivo. Biomaterials 2018, 178, 302-316. [CrossRef]

79. Jhan, Y.Y.; Prasca-Chamorro, D.; Palou Zuniga, G.; Moore, D.M.; Arun Kumar, S.; Gaharwar, A.K.; Bishop, C.J. Engineered extracellular vesicles with synthetic lipids via membrane fusion to establish efficient gene delivery. Int. J. Pharm. 2020, 573, 118802. [CrossRef]

80. Park, O.; Choi, E.S.; Yu, G.; Kim, J.Y.; Kang, Y.Y.; Jung, H.; Mok, H. Efficient delivery of tyrosinase related protein-2 (TRP2) peptides to lymph nodes using serum-derived exosomes. Macromol. Biosci. 2018, 18, e1800301. [CrossRef]

81. Lamichhane, T.N.; Jeyaram, A.; Patel, D.B.; Parajuli, B.; Livingston, N.K.; Arumugasaamy, N.; Schardt, J.S.; Jay, S.M. Oncogene knockdown via active loading of small RNAs into extracellular vesicles by sonication. Cell. Mol. Bioeng. 2016, 9, 315-324. [CrossRef] [PubMed] 
82. Haney, M.J.; Klyachko, N.L.; Harrison, E.B.; Zhao, Y.; Kabanov, A.V.; Batrakova, E.V. TPP1 Delivery to lysosomes with extracellular vesicles and their enhanced brain distribution in the animal model of batten disease. Adv. Healthc. Mater. 2019, 8, e1801271. [CrossRef] [PubMed]

83. Rayamajhi, S.; Nguyen, T.D.T.; Marasini, R.; Aryal, S. Macrophage-derived exosome-mimetic hybrid vesicles for tumor targeted drug delivery. Acta Biomater. 2019, 94, 482-494. [CrossRef]

84. Yu, M.; Gai, C.; Li, Z.; Ding, D.; Zheng, J.; Zhang, W.; Lv, S.; Li, W. Targeted exosome-encapsulated erastin induced ferroptosis in triple negative breast cancer cells. Cancer Sci. 2019, 110, 3173-3182. [CrossRef]

85. Kim, M.S.; Haney, M.J.; Zhao, Y.; Yuan, D.; Deygen, I.; Klyachko, N.L.; Kabanov, A.V.; Batrakova, E.V. Engineering macrophage-derived exosomes for targeted paclitaxel delivery to pulmonary metastases: In vitro and in vivo evaluations. Nanomedicine 2018, 14, 195-204. [CrossRef] [PubMed]

86. Go, G.; Lee, J.; Choi, D.S.; Kim, S.S.; Gho, Y.S. Extracellular vesicle-mimetic ghost nanovesicles for delivering anti-inflammatory drugs to mitigate gram-negative bacterial outer membrane vesicle-induced systemic inflammatory response syndrome. Adv. Healthc. Mater. 2019, 8, e1801082. [CrossRef]

87. Matsuda, A.; Moirangthem, A.; Angom, R.S.; Ishiguro, K.; Driscoll, J.; Yan, I.K.; Mukhopadhyay, D.; Patel, T. Safety of bovine milk derived extracellular vesicles used for delivery of RNA therapeutics in zebrafish and mice. J. Appl. Toxicol. 2020, 40, 706-718. [CrossRef]

88. Hu, G.; Liao, K.; Niu, F.; Yang, L.; Dallon, B.W.; Callen, S.; Tian, C.; Shu, J.; Cui, J.; Sun, Z.; et al. Astrocyte EV-induced lincRNA-Cox2 regulates microglial phagocytosis: Implications for morphine-mediated neurodegeneration. Mol. Ther. Nucleic Acids 2018, 13, 450-463. [CrossRef]

89. Wang, X.; Zhang, H.; Bai, M.; Ning, T.; Ge, S.; Deng, T.; Liu, R.; Zhang, L.; Ying, G.; Ba, Y. Exosomes serve as nanoparticles to deliver anti-miR-214 to reverse chemoresistance to cisplatin in gastric cancer. Mol. Ther. 2018, 26, 774-783. [CrossRef]

90. Kang, J.Y.; Park, H.; Kim, H.; Mun, D.; Park, H.; Yun, N.; Joung, B. Human peripheral blood-derived exosomes for microRNA delivery. Int. J. Mol. Med. 2019, 43, 2319-2328. [CrossRef]

91. Gao, J.; Wang, S.; Wang, Z. High yield, scalable and remotely drug-loaded neutrophil-derived extracellular vesicles (EVs) for anti-inflammation therapy. Biomaterials 2017, 135, 62-73. [CrossRef] [PubMed]

92. Monfared, H.; Jahangard, Y.; Nikkhah, M.; Mirnajafi-Zadeh, J.; Mowla, S.J. Potential therapeutic effects of exosomes packed with a mir-21-sponge construct in a rat model of glioblastoma. Front. Oncol. 2019, 9, 782. [CrossRef]

93. Sutaria, D.S.; Jiang, J.; Elgamal, O.A.; Pomeroy, S.M.; Badawi, M.; Zhu, X.; Pavlovicz, R.; Azevedo-Pouly, A.C.P.; Chalmers, J.; Li, C.; et al. Low active loading of cargo into engineered extracellular vesicles results in inefficient miRNA mimic delivery. J. Extracell. Vesicles 2017, 6, 1333882. [CrossRef] [PubMed]

94. Heath, N.; Osteikoetxea, X.; de Oliveria, T.M.; Lázaro-Ibáñez, E.; Shatnyeva, O.; Schindler, C.; Tigue, N.; Mayr, L.M.; Dekker, N.; Overman, R.; et al. Endosomal escape enhancing compounds facilitate functional delivery of extracellular vesicle cargo. Nanomedicine 2019, 14, 2799-2814. [CrossRef]

95. Bliss, S.A.; Sinha, G.; Sandiford, O.A.; Williams, L.M.; Engelberth, D.J.; Guiro, K.; Isenalumhe, L.L.; Greco, S.J.; Ayer, S.; Bryan, M.; et al. Mesenchymal stem cell-derived exosomes stimulate cycling quiescence and early breast cancer dormancy in bone marrow. Cancer Res. 2016, 76, 5832-5844. [CrossRef]

96. Bose, R.J.C.; Uday Kumar, S.; Zeng, Y.; Afjei, R.; Robinson, E.; Lau, K.; Bermudez, A.; Habte, F.; Pitteri, S.J.; Sinclair, R.; et al. Tumor cell-derived extracellular vesicle-coated nanocarriers: An efficient theranostic platform for the cancer-specific delivery of anti-miR-21 and imaging agents. ACS Nano 2018, 12, 10817-10832. [CrossRef]

97. Hung, M.E.; Leonard, J.N. A platform for actively loading cargo RNA to elucidate limiting steps in EV-mediated delivery. J. Extracell. Vesicles 2016, 5, 31027. [CrossRef] [PubMed]

98. You, H.J.; Fang, S.B.; Wu, T.T.; Zhang, H.; Feng, Y.K.; Li, X.J.; Yang, H.H.; Li, G.; Li, X.H.; Wu, C.; et al. Mesenchymal stem cell-derived exosomes improve motor function and attenuate neuropathology in a mouse model of Machado-Joseph disease. Stem Cell. Res. Ther. 2020, 11, 222. [CrossRef]

99. Brossa, A.; Fonsato, V.; Grange, C.; Tritta, S.; Tapparo, M.; Calvetti, R.; Cedrino, M.; Fallo, S.; Gontero, P.; Camussi, G.; et al. Extracellular vesicles from human liver stem cells inhibit renal cancer stem cell-derived tumor growth in vitro and in vivo. Int. J. Cancer 2020, 147, 1694-1706. [CrossRef]

100. Campanella, C.; Caruso Bavisotto, C.; Logozzi, M.; Marino Gammazza, A.; Mizzoni, D.; Cappello, F.; Fais, S. On the choice of the extracellular vesicles for therapeutic purposes. Int. J. Mol. Sci. 2019, 20, 236. [CrossRef] 
101. Ubogu, E.E. Biology of the human blood-nerve barrier in health and disease. Exp. Neurol. 2020, 328, 113272. [CrossRef] [PubMed]

102. Li, C.; Li, X.; Zhao, B.; Wang, C. Exosomes derived from miR-544-modified mesenchymal stem cells promote recovery after spinal cord injury. Arch. Physiol. Biochem. 2020, 126, 369-375. [CrossRef] [PubMed]

103. Yang, Y.; Ye, Y.; Kong, C.; Su, X.; Zhang, X.; Bai, W.; He, X. MiR-124 enriched exosomes promoted the M2 polarization of microglia and enhanced hippocampus neurogenesis after traumatic brain injury by inhibiting TLR4 pathway. Neurochem. Res. 2019, 44, 811-828. [CrossRef] [PubMed]

104. Xin, H.; Katakowski, M.; Wang, F.; Qian, J.Y.; Liu, X.S.; Ali, M.M.; Buller, B.; Zhang, Z.G.; Chopp, M. MicroRNA cluster miR-17-92 cluster in exosomes enhance neuroplasticity and functional recovery after stroke in rats. Stroke 2017, 48,747-753. [CrossRef]

105. Bonafede, R.; Turano, E.; Scambi, I.; Busato, A.; Bontempi, P.; Virla, F.; Schiaffino, L.; Marzola, P.; Bonetti, B.; Mariotti, R. ASC-exosomes ameliorate the disease progression in SOD1(G93A) murine model underlining their potential therapeutic use in human ALS. Int. J. Mol. Sci. 2020, 21, 3651. [CrossRef]

106. Kim, G.; Kim, M.; Lee, Y.; Byun, J.W.; Hwang, D.W.; Lee, M. Systemic delivery of microRNA-21 antisense oligonucleotides to the brain using T7-peptide decorated exosomes. J. Control. Release 2020, 317, $273-281$. [CrossRef]

107. Alvarez-Erviti, L.; Seow, Y.; Yin, H.; Betts, C.; Lakhal, S.; Wood, M.J. Delivery of siRNA to the mouse brain by systemic injection of targeted exosomes. Nat. Biotechnol. 2011, 29, 341-345. [CrossRef]

108. Zhang, L.; Liu, H.; Jia, L.; Lyu, J.; Sun, Y.; Yu, H.; Li, H.; Liu, W.; Weng, Y.; Yu, W. Exosomes mediate hippocampal and cortical neuronal injury induced by hepatic ischemia-reperfusion injury through activating pyroptosis in rats. Oxid. Med. Cell Longev. 2019, 2019, 3753485. [CrossRef]

109. Monroe, M.N.; Zhaorigetu, S.; Gupta, V.S.; Jin, D.; Givan, K.D.; Curylo, A.L.; Olson, S.D.; Cox, C.S.; Segura, A.; Buja, L.M.; et al. Extracellular vesicles influence the pulmonary arterial extracellular matrix in congenital diaphragmatic hernia. Pediatr. Pulmonol. 2020. [CrossRef]

110. Liu, Z.; Wu, C.; Zou, X.; Shen, W.; Yang, J.; Zhang, X.; Hu, X.; Wang, H.; Liao, Y.; Jing, T. Exosomes derived from mesenchymal stem cells inhibit neointimal hyperplasia by activating the Erk1/2 signalling pathway in rats. Stem Cell. Res. Ther. 2020, 11, 220. [CrossRef]

111. Gu, X.; Li, Y.; Chen, K.; Wang, X.; Wang, Z.; Lian, H.; Lin, Y.; Rong, X.; Chu, M.; Lin, J.; et al. Exosomes derived from umbilical cord mesenchymal stem cells alleviate viral myocarditis through activating AMPK/mTOR-mediated autophagy flux pathway. J. Cell Mol. Med. 2020, 24, 7515-7530. [CrossRef]

112. Liu, J.; Chen, T.; Lei, P.; Tang, X.; Huang, P. Exosomes released by bone marrow mesenchymal stem cells attenuate lung injury induced by intestinal ischemia reperfusion via the TLR4/NF-kB pathway. Int. J. Med. Sci. 2019, 16, 1238-1244. [CrossRef]

113. Mahdipour, E.; Salmasi, Z.; Sabeti, N. Potential of stem cell-derived exosomes to regenerate $\beta$ islets through Pdx-1 dependent mechanism in a rat model of type 1 diabetes. J. Cell Physiol. 2019, 234, 20310-20321. [CrossRef] [PubMed]

114. Liu, Y.; Lou, G.; Li, A.; Zhang, T.; Qi, J.; Ye, D.; Zheng, M.; Chen, Z. AMSC-derived exosomes alleviate lipopolysaccharide/d-galactosamine-induced acute liver failure by miR-17-mediated reduction of TXNIP/NLRP3 inflammasome activation in macrophages. EBioMedicine 2018, 36, 140-150. [CrossRef]

115. Yang, J.; Liu, X.X.; Fan, H.; Tang, Q.; Shou, Z.X.; Zuo, D.M.; Zou, Z.; Xu, M.; Chen, Q.Y.; Peng, Y.; et al. extracellular vesicles derived from bone marrow mesenchymal stem cells protect against experimental colitis via attenuating colon inflammation, oxidative stress and apoptosis. PLoS ONE 2015, 10, e0140551. [CrossRef]

116. Grange, C.; Papadimitriou, E.; Dimuccio, V.; Pastorino, C.; Molina, J.; O’Kelly, R.; Niedernhofer, L.J.; Robbins, P.D.; Camussi, G.; Bussolati, B. Urinary extracellular vesicles carrying klotho improve the recovery of renal function in an acute tubular injury model. Mol. Ther. 2020, 28, 490-502. [CrossRef] [PubMed]

117. Wang, L.; Chopp, M.; Szalad, A.; Lu, X.; Zhang, Y.; Wang, X.; Cepparulo, P.; Lu, M.; Li, C.; Zhang, Z.G. Exosomes derived from schwann cells ameliorate peripheral neuropathy in type 2 diabetic mice. Diabetes 2020, 69, 749-759. [CrossRef]

118. Jiang, K.; Yang, J.; Guo, S.; Zhao, G.; Wu, H.; Deng, G. peripheral circulating exosome-mediated delivery of miR-155 as a novel mechanism for acute lung inflammation. Mol. Ther. 2019, 27, 1758-1771. [CrossRef]

119. Milano, G.; Biemmi, V.; Lazzarini, E.; Balbi, C.; Ciullo, A.; Bolis, S.; Ameri, P.; Di Silvestre, D.; Mauri, P.; Barile, L.; et al. Intravenous administration of cardiac progenitor cell-derived exosomes protects against doxorubicin/trastuzumab-induced cardiac toxicity. Cardiovasc. Res. 2020, 116, 383-392. [CrossRef] [PubMed] 
120. Ciullo, A.; Biemmi, V.; Milano, G.; Bolis, S.; Cervio, E.; Fertig, E.T.; Gherghiceanu, M.; Moccetti, T.; Camici, G.G.; Vassalli, G.; et al. Exosomal expression of CXCR4 targets cardioprotective vesicles to myocardial infarction and improves outcome after systemic administration. Int. J. Mol. Sci. 2019, 20, 468. [CrossRef] [PubMed]

121. Vandergriff, A.; Huang, K.; Shen, D.; Hu, S.; Hensley, M.T.; Caranasos, T.G.; Qian, L.; Cheng, K. Targeting regenerative exosomes to myocardial infarction using cardiac homing peptide. Theranostics 2018, 8, 1869-1878. [CrossRef] [PubMed]

122. Ge, X.; Guo, M.; Hu, T.; Li, W.; Huang, S.; Yin, Z.; Li, Y.; Chen, F.; Zhu, L.; Kang, C.; et al. Increased microglial exosomal miR-124-3p alleviates neurodegeneration and improves cognitive outcome after rmTBI. Mol. Ther. 2020, 28, 503-522. [CrossRef]

123. Song, Y.; Li, Z.; He, T.; Qu, M.; Jiang, L.; Li, W.; Shi, X.; Pan, J.; Zhang, L.; Wang, Y.; et al. M2 microglia-derived exosomes protect the mouse brain from ischemia-reperfusion injury via exosomal miR-124. Theranostics 2019, 9, 2910-2923. [CrossRef] [PubMed]

124. Venkat, P.; Cui, C.; Chopp, M.; Zacharek, A.; Wang, F.; Landschoot-Ward, J.; Shen, Y.; Chen, J. MiR-126 mediates brain endothelial cell exosome treatment-induced neurorestorative effects after stroke in type 2 diabetes mellitus mice. Stroke 2019, 50, 2865-2874. [CrossRef]

125. Nie, H.; Xie, X.; Zhang, D.; Zhou, Y.; Li, B.; Li, F.; Li, F.; Cheng, Y.; Mei, H.; Meng, H.; et al. Use of lung-specific exosomes for miRNA-126 delivery in non-small cell lung cancer. Nanoscale 2020, 12, 877-887. [CrossRef]

126. Yong, T.; Zhang, X.; Bie, N.; Zhang, H.; Zhang, X.; Li, F.; Hakeem, A.; Hu, J.; Gan, L.; Santos, H.A.; et al. Tumor exosome-based nanoparticles are efficient drug carriers for chemotherapy. Nat. Commun. 2019, 10, 3838. [CrossRef]

127. Maia, J.; Caja, S.; Strano Moraes, M.C.; Couto, N.; Costa-Silva, B. Exosome-based cell-cell communication in the tumor microenvironment. Front. Cell Dev. Biol. 2018, 6, 18. [CrossRef] [PubMed]

128. Kodali, M.; Castro, O.W.; Kim, D.K.; Thomas, A.; Shuai, B.; Attaluri, S.; Upadhya, R.; Gitai, D.; Madhu, L.N.; Prockop, D.J.; et al. Intranasally administered human MSC-derived extracellular vesicles pervasively incorporate into neurons and microglia in both intact and status epilepticus injured forebrain. Int. J. Mol. Sci. 2019, 21, 181. [CrossRef]

129. Guo, S.; Perets, N.; Betzer, O.; Ben-Shaul, S.; Sheinin, A.; Michaelevski, I.; Popovtzer, R.; Offen, D.; Levenberg, S. Intranasal delivery of mesenchymal stem cell derived exosomes loaded with phosphatase and tensin homolog siRNA repairs complete spinal cord injury. ACS Nano 2019, 13, 10015-10028. [CrossRef] [PubMed]

130. Thomi, G.; Joerger-Messerli, M.; Haesler, V.; Muri, L.; Surbek, D.; Schoeberlein, A. Intranasally administered exosomes from umbilical cord stem cells have preventive neuroprotective effects and contribute to functional recovery after perinatal brain injury. Cells 2019, 8, 855. [CrossRef] [PubMed]

131. Thomi, G.; Surbek, D.; Haesler, V.; Joerger-Messerli, M.; Schoeberlein, A. Exosomes derived from umbilical cord mesenchymal stem cells reduce microglia-mediated neuroinflammation in perinatal brain injury. Stem Cell Res. Ther. 2019, 10, 105. [CrossRef] [PubMed]

132. Zhuang, X.; Xiang, X.; Grizzle, W.; Sun, D.; Zhang, S.; Axtell, R.C.; Ju, S.; Mu, J.; Zhang, L.; Steinman, L.; et al. Treatment of brain inflammatory diseases by delivering exosome encapsulated anti-inflammatory drugs from the nasal region to the brain. Mol. Ther. 2011, 19, 1769-1779. [CrossRef] [PubMed]

133. Scholl, J.N.; de Fraga Dias, A.; Pizzato, P.R.; Lopes, D.V.; Moritz, C.E.J.; Jandrey, E.H.F.; Souto, G.D.; Colombo, M.; Rohden, F.; Sevigny, J.; et al. Characterization and antiproliferative activity of glioma-derived extracellular vesicles. Nanomedicine 2020, 15, 1001-1018. [CrossRef] [PubMed]

134. Narbute, K.; Pilipenko, V.; Pupure, J.; Dzirkale, Z.; Jonavičè, U.; Tunaitis, V.; Kriaučiūnaitė, K.; Jarmalavičiūtè, A.; Jansone, B.; Kluša, V.; et al. Intranasal administration of extracellular vesicles derived from human teeth stem cells improves motor symptoms and normalizes tyrosine hydroxylase expression in the substantia nigra and striatum of the 6-hydroxydopamine-treated rats. Stem Cells Transl. Med. 2019, 8, 490-499. [CrossRef]

135. Singh, P.P.; Smith, V.L.; Karakousis, P.C.; Schorey, J.S. Exosomes isolated from mycobacteria-infected mice or cultured macrophages can recruit and activate immune cells in vitro and in vivo. J. Immunol. 2012, 189, 777-785. [CrossRef]

136. Prado, N.; Cañamero, M.; Villalba, M.; Rodríguez, R.; Batanero, E. Bystander suppression to unrelated allergen sensitization through intranasal administration of tolerogenic exosomes in mouse. Mol. Immunol. 2010, 47, 2148-2151. [CrossRef] 
137. Trelis, M.; Galiano, A.; Bolado, A.; Toledo, R.; Marcilla, A.; Bernal, D. Subcutaneous injection of exosomes reduces symptom severity and mortality induced by Echinostoma caproni infection in BALB/c mice. Int. J. Parasitol. 2016, 46, 799-808. [CrossRef]

138. Cho, B.S.; Kim, J.O.; Ha, D.H.; Yi, Y.W. Exosomes derived from human adipose tissue-derived mesenchymal stem cells alleviate atopic dermatitis. Stem Cell Res. Ther. 2018, 9, 187. [CrossRef]

139. Del Cacho, E.; Gallego, M.; Lillehoj, H.S.; Quilez, J.; Lillehoj, E.P.; Sánchez-Acedo, C. Induction of protective immunity against experimental Eimeria tenella infection using serum exosomes. Vet. Parasitol. 2016, 224, 1-6. [CrossRef]

140. Wang, H.; Wang, B.; Zhang, A.; Hassounah, F.; Seow, Y.; Wood, M.; Ma, F.; Klein, J.D.; Price, S.R.; Wang, X.H. Exosome-mediated miR-29 transfer reduces muscle atrophy and kidney fibrosis in mice. Mol. Ther. 2019, 27, 571-583. [CrossRef]

141. Ju, C.; Li, Y.; Shen, Y.; Liu, Y.; Cai, J.; Liu, N.; Ma, G.; Tang, Y. Transplantation of Cardiac Mesenchymal Stem Cell-Derived Exosomes for Angiogenesis. J. Cardiovasc. Transl. Res. 2018, 11, 429-437. [CrossRef]

142. Hu, G.-W.; Li, Q.; Niu, X.; Hu, B.; Liu, J.; Zhou, S.-M.; Guo, S.-C.; Lang, H.-L.; Zhang, C.-Q.; Wang, Y.; et al. Exosomes secreted by human-induced pluripotent stem cell-derived mesenchymal stem cells attenuate limb ischemia by promoting angiogenesis in mice. Stem Cell Res. Ther. 2015, 6, 1-15. [CrossRef]

143. Zhou, X.; Li, Z.; Sun, W.; Yang, G.; Xing, C.; Yuan, L. Delivery efficacy differences of intravenous and intraperitoneal injection of exosomes: Perspectives from tracking dye labeled and MiRNA encapsulated exosomes. Curr. Drug Deliv. 2020, 17, 186-194. [CrossRef]

144. Betker, J.L.; Angle, B.M.; Graner, M.W.; Anchordoquy, T.J. The potential of exosomes from cow milk for oral delivery. J. Pharm. Sci. 2019, 108, 1496-1505. [CrossRef] [PubMed]

145. Manca, S.; Upadhyaya, B.; Mutai, E.; Desaulniers, A.T.; Cederberg, R.A.; White, B.R.; Zempleni, J. Milk exosomes are bioavailable and distinct microRNA cargos have unique tissue distribution patterns. Sci. Rep. 2018, 8, 11321. [CrossRef] [PubMed]

146. Safwat, A.; Sabry, D.; Ragiae, A.; Amer, E.; Mahmoud, R.H.; Shamardan, R.M. Adipose mesenchymal stem cells-derived exosomes attenuate retina degeneration of streptozotocin-induced diabetes in rabbits. J. Circ. Biomark. 2018, 7, 1849454418807827. [CrossRef] [PubMed]

147. Huang, P.; Wang, L.; Li, Q.; Xu, J.; Xu, J.; Xiong, Y.; Chen, G.; Qian, H.; Jin, C.; Yu, Y.; et al. Combinatorial treatment of acute myocardial infarction using stem cells and their derived exosomes resulted in improved heart performance. Stem Cell Res. Ther. 2019, 10, 1-12. [CrossRef]

148. Shiue, S.-J.; Rau, R.-H.; Shiue, H.-S.; Hung, Y.-W.; Li, Z.-X.; Yang, K.D.; Cheng, J.-K. Mesenchymal stem cell exosomes as a cell-free therapy for nerve injury-induced pain in rats. Pain 2019, 160, 210-223. [CrossRef] [PubMed]

149. Smyth, T.; Kullberg, M.; Malik, N.; Smith-Jones, P.; Graner, M.W.; Anchordoquy, T.J. Biodistribution and delivery efficiency of unmodified tumor-derived exosomes. J. Control. Release 2015, 199, 145-155. [CrossRef]

150. Zhang, H.; Freitas, D.; Kim, H.S.; Fabijanic, K.; Li, Z.; Chen, H.; Mark, M.T.; Molina, H.; Benito-Martin, A.; Bojmar, L.; et al. Identification of distinct nanoparticles and subsets of extracellular vesicles by asymmetric flow field-flow fractionation. Nat. Cell Biol. 2018, 20, 332-343. [CrossRef]

151. Dasgupta, D.; Nakao, Y.; Mauer, A.S.; Thompson, J.M.; Sehrawat, T.S.; Liao, C.-Y.; Krishnan, A.; Lucien, F.; Guo, Q.; Liu, M.; et al. IRE1A stimulates hepatocyte-derived extracellular vesicles that promote inflammation in mice with steatohepatitis. Gastroenterology 2020, 20, 34831-34839. [CrossRef] [PubMed]

152. Han, C.; Xiong, N.; Guo, X.; Huang, J.; Ma, K.; Liu, L.; Xia, Y.; Shen, Y.; Li, J.; Jiang, H.; et al. Exosomes from patients with Parkinson's disease are pathological in mice. J. Mol. Med. 2019, 97, 1329-1344. [CrossRef] [PubMed]

153. Gao, K.; Jin, J.; Huang, C.; Li, J.; Luo, H.; Li, L.; Huang, Y.; Jiang, Y. Exosomes derived from septic mouse serum modulate immune responses via exosome-associated cytokines. Front. Immunol. 2019, 10, 1560. [CrossRef]

154. Pan, T.; Jia, P.; Chen, N.; Fang, Y.; Liang, Y.; Guo, M.; Ding, X. Delayed remote ischemic preconditioning confersrenoprotection against septic acute kidney injury via exosomal miR-21. Theranostics 2019, 9, 405-423. [CrossRef] [PubMed] 
155. Melzer, C.; Rehn, V.; Yang, Y.; Bähre, H.; Von Der Ohe, J.; Hass, R. Taxol-loaded MSC-derived exosomes provide a therapeutic vehicle to target metastatic breast cancer and other carcinoma cells. Cancers 2019, 11, 798. [CrossRef]

156. Tamura, R.; Uemoto, S.; Tabata, Y. Immunosuppressive effect of mesenchymal stem cell-derived exosomes on a concanavalin A-induced liver injury model. Inflamm. Regen. 2016, 36, 1-11. [CrossRef]

157. Li, J.; Xue, H.; Li, T.; Chu, X.; Xin, D.; Xiong, Y.; Qiu, W.; Gao, X.; Qian, M.; Xu, J.; et al. Exosomes derived from mesenchymal stem cells attenuate the progression of atherosclerosis in ApoE-/- mice via miR-let7 mediated infiltration and polarization of M2 macrophage. Biochem. Biophys. Res. Commun. 2019, 510, 565-572. [CrossRef]

158. Zhu, L.-P.; Tian, T.; Wang, J.-Y.; He, J.-N.; Chen, T.; Pan, M.; Xu, L.; Zhang, H.-X.; Qiu, X.-T.; Li, C.-C.; et al. Hypoxia-elicited mesenchymal stem cell-derived exosomes facilitates cardiac repair through miR-125b-mediated prevention of cell death in myocardial infarction. Theranostics 2018, 8, 6163-6177. [CrossRef]

159. Wen, S.; Dooner, M.; Cheng, Y.; Papa, E.; Del Tatto, M.; Pereira, M.; Deng, Y.; Goldberg, L.; Aliotta, J.; Chatterjee, D.; et al. Mesenchymal stromal cell-derived extracellular vesicles rescue radiation damage to murine marrow hematopoietic cells. Leukemia 2016, 30, 2221-2231. [CrossRef]

160. Nakano, M.; Nagaishi, K.; Konari, N.; Saito, Y.; Chikenji, T.; Mizuec, Y.; Fujimiya, M. Bone marrow-derived mesenchymal stem cells improve diabetes-induced cognitive impairment by exosome transfer into damaged neurons and astrocytes. Sci. Rep. 2016, 6, 24805. [CrossRef]

161. Lou, G.; Chen, L.; Xia, C.; Wang, W.; Qi, J.; Li, A.; Zhao, L.; Chen, Z.; Zheng, M.; Liu, Y. MiR-199a-modified exosomes from adipose tissue-derived mesenchymal stem cells improve hepatocellular carcinoma chemosensitivity through mTOR pathway. J. Exp. Clin. Cancer Res. 2020, 39, 1-9. [CrossRef] [PubMed]

162. Wang, L.; Hu, L.; Zhou, X.; Xiong, Z.; Zhang, C.; Shehada, H.M.A.; Hu, B.; Song, J.; Chen, L. Exosomes secreted by human adipose mesenchymal stem cells promote scarless cutaneous repair by regulating extracellular matrix remodelling. Sci. Rep. 2017, 7, 1-12. [CrossRef] [PubMed]

163. Luo, Z.-W.; Li, F.-X.-Z.; Liu, Y.-W.; Rao, S.-S.; Yin, H.; Huang, J.; Chen, C.-Y.; Hu, Y.; Zhang, Y.; Tan, Y.-J.; et al. Aptamer-functionalized exosomes from bone marrow stromal cells target bone to promote bone regeneration. Nanoscale 2019, 11, 20884-20892. [CrossRef] [PubMed]

164. Zou, X.; Yuan, M.; Zhang, T.; Wei, H.; Xu, S.; Jiang, N.; Zheng, N.; Wu, Z. Extracellular vesicles expressing a single-chain variable fragment of an HIV-1 specific antibody selectively target Env+ tissues. Theranostics 2019, 9, 5657-5671. [CrossRef]

165. Zhang, K.; Shao, C.-X.; Zhu, J.-D.; Lv, X.-L.; Tu, C.-Y.; Jiang, C.; Shang, M.-J. Exosomes function as nanoparticles to transfer miR-199a-3p to reverse chemoresistance to cisplatin in hepatocellular carcinoma. Biosci. Rep. 2020, 40, 40. [CrossRef]

166. Ohno, S.-I.; Takanashi, M.; Sudo, K.; Ueda, S.; Ishikawa, A.; Matsuyama, N.; Fujita, K.; Mizutani, T.; Ohgi, T.; Ochiya, T.; et al. Systemically injected exosomes targeted to EGFR deliver antitumor microRNA to breast cancer cells. Mol. Ther. 2013, 21, 185-191. [CrossRef]

167. Wei, G.; Jie, Y.; Haibo, L.; Chaoneng, W.; Dong, H.; Jianbing, Z.; Junjie, G.; Leilei, M.; Hongtao, S.; Zou, Y.; et al. Dendritic cells derived exosomes migration to spleen and induction of inflammation are regulated by CCR7. Sci. Rep. 2017, 7, srep42996. [CrossRef]

168. Tian, Y.; Li, S.; Song, J.; Ji, T.; Zhu, M.; Anderson, G.J.; Wei, J.; Nie, G. A doxorubicin delivery platform using engineered natural membrane vesicle exosomes for targeted tumor therapy. Biomaterials 2014, 35, 2383-2390. [CrossRef]

169. Viñas, J.L.; Spence, M.; Gutsol, A.; Knoll, W.; Burger, D.; Zimpelmann, J.; Allan, D.S.; Burns, K.D. Receptor-ligand interaction mediates targeting of endothelial colony forming cell-derived exosomes to the kidney after ischemic injury. Sci. Rep. 2018, 8, 16320. [CrossRef]

170. Yang, S.; Xia, Y.-P.; Luo, X.-Y.; Chen, S.-L.; Li, B.-W.; Ye, Z.-M.; Chen, S.-C.; Mao, L.; Jin, H.-J.; Li, Y.-N.; et al. Exosomal CagA derived from Helicobacter pylori-infected gastric epithelial cells induces macrophage foam cell formation and promotes atherosclerosis. J. Mol. Cell. Cardiol. 2019, 135, 40-51. [CrossRef]

171. Sun, X.; Jung, J.-H.; Arvola, O.; Santoso, M.R.; Giffard, R.G.; Yang, P.C.; Stary, C.M. Stem cell-derived exosomes protect astrocyte cultures from in vitro ischemia and decrease injury as post-stroke intravenous therapy. Front. Cell. Neurosci. 2019, 13, 394. [CrossRef] [PubMed] 
172. Nishida-Aoki, N.; Tominaga, N.; Kosaka, N.; Ochiya, T. Altered biodistribution of deglycosylated extracellular vesicles through enhanced cellular uptake. J. Extracell. Vesicles 2020, 9, 1713527. [CrossRef] [PubMed]

173. Wu, J.; Dong, T.; Chen, T.; Sun, J.; Luo, J.; He, J.; Wei, L.; Zeng, B.; Zhang, H.; Li, W.; et al. Hepatic exosome-derived miR-130a-3p attenuates glucose intolerance via suppressing PHLPP2 gene in adipocyte. Metabolism 2020, 103, 154006. [CrossRef] [PubMed]

174. Pei, X.; Li, Y.; Zhu, L.; Zhou, Z. Astrocyte-derived exosomes suppress autophagy and ameliorate neuronal damage in experimental ischemic stroke. Exp. Cell Res. 2019, 382, 111474. [CrossRef] [PubMed]

175. Ren, W.; Zhang, X.; Li, W.; Feng, Q.; Feng, H.; Tong, Y.; Rong, H.; Wang, W.; Zhang, D.; Zhang, Z.; et al. Exosomal miRNA-107 induces myeloid-derived suppressor cell expansion in gastric cancer. Cancer Manag. Res. 2019, 11, 4023-4040. [CrossRef] [PubMed]

176. Erb, U.; Zhao, K.; Wang, Z.; Xiao, L.; Zöller, M. Murine and human pancreatic tumor exosome recovery in mouse serum: Diagnostic and prognostic potential and target cell delivery. Cancer Lett. 2017, 403, 1-12. [CrossRef]

177. Yuan, D.; Zhao, Y.; Banks, W.A.; Bullock, K.M.; Haney, M.; Batrakova, E.; Kabanov, A.V. Macrophage exosomes as natural nanocarriers for protein delivery to inflamed brain. Biomaterials 2017, 142, 1-12. [CrossRef] [PubMed]

178. Ye, Z.; Zhang, T.; He, W.; Jin, H.; Liu, C.; Yang, Z.; Ren, J. Methotrexate-loaded extracellular vesicles functionalized with therapeutic and targeted peptides for the treatment of glioblastoma multiforme. ACS Appl. Mater. Interfaces 2018, 10, 12341-12350. [CrossRef]

179. Yang, H.-C.; Zhang, M.; Wu, R.; Zheng, H.-Q.; Zhang, L.-Y.; Luo, J.; Li, L.-L.; Hu, X.-Q. C-C chemokine receptor type 2-overexpressing exosomes alleviated experimental post-stroke cognitive impairment by enhancing microglia/macrophage M2 polarization. World J. Stem Cells 2020, 12, 152-167. [CrossRef]

180. Romanelli, P.; Bieler, L.; Scharler, C.; Pachler, K.; Kreutzer, C.; Zaunmair, P.; Jakubecova, D.; Mrowetz, H.; Benedetti, B.; Rivera, F.J.; et al. Extracellular vesicles can deliver anti-inflammatory and anti-scarring activities of mesenchymal stromal cells after spinal cord injury. Front. Neurol. 2019, 10, 1225. [CrossRef]

181. Wang, L.; Pei, S.; Han, L.; Guo, B.; Li, Y.; Duan, R.; Yao, Y.; Xue, B.; Chen, X.; Jia, Y. Mesenchymal stem cell-derived exosomes reduce a1 astrocytes via downregulation of phosphorylated NFKB P65 subunit in spinal cord injury. Cell. Physiol. Biochem. 2018, 50, 1535-1559. [CrossRef] [PubMed]

182. Qu, Q.; Pang, Y.; Zhang, C.; Liu, L.; Bi, Y. Exosomes derived from human umbilical cord mesenchymal stem cells inhibit vein graft intimal hyperplasia and accelerate reendothelialization by enhancing endothelial function. Stem Cell Res. Ther. 2020, 11, 133. [CrossRef] [PubMed]

183. Lin, Y.; Zhang, F.; Lian, X.F.; Peng, W.Q.; Yin, C.Y. Mesenchymal stem cell-derived exosomes improve diabetes mellitus-induced myocardial injury and fibrosis via inhibition of TGF- $\beta 1 /$ Smad 2 signaling pathway. Cell. Mol. Biol. 2019, 65, 123-126. [CrossRef] [PubMed]

184. Yu, T.; Zhao, C.; Hou, S.; Zhou, W.; Wang, B.; Chen, Y. Exosomes secreted from miRNA-29b-modified mesenchymal stem cells repaired spinal cord injury in rats. Braz. J. Med Biol. Res. 2019, 52, e8735. [CrossRef]

185. Zuo, R.; Liu, M.; Wang, Y.; Li, J.; Wang, W.; Wu, J.; Sun, C.; Li, B.; Wang, Z.; Lan, W.; et al. BM-MSC-derived exosomes alleviate radiation-induced bone loss by restoring the function of recipient BM-MSCs and activating Wnt/ $\beta$-catenin signaling. Stem Cell Res. Ther. 2019, 10, 1-13. [CrossRef]

186. Wang, J.; Mi, Y.; Wu, S.; You, X.; Huang, Y.; Zhu, J.; Zhu, L. Exosomes from adipose-derived stem cells protect against high glucose-induced erectile dysfunction by delivery of corin in a streptozotocin-induced diabetic rat model. Regen. Ther. 2020, 14, 227-233. [CrossRef]

187. Geng, W.; Tang, H.; Luo, S.; Lv, Y.; Liang, D.; Kang, X.; Hong, W. Exosomes from miRNA-126-modified ADSCs promotes functional recovery after stroke in rats by improving neurogenesis and suppressing microglia activation. Am. J. Transl. Res. 2019, 11, 780-792.

188. Patel, N.A.; Moss, L.D.; Lee, J.-Y.; Tajiri, N.; Acosta, S.; Hudson, C.; Parag, S.; Cooper, D.R.; Borlongan, C.V.; Bickford, P.C. Long noncoding RNA MALAT1 in exosomes drives regenerative function and modulates inflammation-linked networks following traumatic brain injury. J. Neuroinflamm. 2018, 15, 1-23. [CrossRef]

189. Chang, C.-L.; Sung, P.-H.; Chen, K.-H.; Shao, P.-L.; Yang, C.-C.; Cheng, B.-C.; Lin, K.-C.; Chen, C.-H.; Chai, H.-T.; Chang, H.-W.; et al. Adipose-derived mesenchymal stem cell-derived exosomes alleviate overwhelming systemic inflammatory reaction and organ damage and improve outcome in rat sepsis syndrome. Am. J. Transl. Res. 2018, 10, 1053-1070. 
190. Chen, K.-H.; Chen, C.-H.; Wallace, C.G.; Yuen, C.-M.; Kao, G.-S.; Chen, Y.-L.; Shao, P.-L.; Chen, Y.-L.; Chai, H.-T.; Lin, K.-C.; et al. Intravenous administration of xenogenic adipose-derived mesenchymal stem cells (ADMSC) and ADMSC-derived exosomes markedly reduced brain infarct volume and preserved neurological function in rat after acute ischemic stroke. Oncotarget 2016, 7, 74537-74556. [CrossRef]

191. Takov, K.; He, Z.; Johnston, H.E.; Timms, J.F.; Guillot, P.V.; Yellon, D.M.; Davidson, S.M. Small extracellular vesicles secreted from human amniotic fluid mesenchymal stromal cells possess cardioprotective and promigratory potential. Basic Res. Cardiol. 2020, 115, 1-22. [CrossRef]

192. Liu, X.; Li, Q.; Niu, X.; Hu, B.; Chen, S.; Song, W.; Ding, J.; Zhang, C.; Wang, Y. Exosomes secreted from human-induced pluripotent stem cell-derived mesenchymal stem cells prevent osteonecrosis of the femoral head by promoting angiogenesis. Int. J. Biol. Sci. 2017, 13, 232-244. [CrossRef]

193. Jiang, Z.-Z.; Liu, Y.-M.; Niu, X.; Yin, J.-Y.; Hu, B.; Guo, S.; Fan, Y.; Wang, Y.; Wang, N. Exosomes secreted by human urine-derived stem cells could prevent kidney complications from type I diabetes in rats. Stem Cell Res. Ther. 2016, 7, 24. [CrossRef]

194. Ren, X.-S.; Tong, Y.; Qiu, Y.; Ye, C.; Wu, N.; Xiong, X.-Q.; Wang, J.-J.; Han, Y.; Zhou, Y.-B.; Zhang, F.; et al. MiR155-5p in adventitial fibroblasts-derived extracellular vesicles inhibits vascular smooth muscle cell proliferation via suppressing angiotensin-converting enzyme expression. J. Extracell. Vesicles 2019, 9, 1698795. [CrossRef]

195. Kim, M.; Kim, G.; Hwang, D.W.; Lee, M. Delivery of high mobility group box-1 sirna using brain-targeting exosomes for ischemic stroke therapy. J. Biomed. Nanotechnol. 2019, 15, 2401-2412. [CrossRef]

196. Dominguez, J.M.; Dominguez, J.H.; Xie, D.; Kelly, K.J. Human extracellular microvesicles from renal tubules reverse kidney ischemia-reperfusion injury in rats. PLoS ONE 2018, 13, e0202550. [CrossRef]

197. Dominguez, J.H.; Liu, Y.; Gao, H.; Dominguez, J.M.; Xie, D.; Kelly, K.J. Renal tubular cell-derived extracellular vesicles accelerate the recovery of established renal ischemia reperfusion injury. J. Am. Soc. Nephrol. 2017, 28, 3533-3544. [CrossRef]

198. Sengupta, V.; Sengupta, S.; Lazo, A.; Woods, P.; Nolan, A.; Bremer, N. Exosomes derived from bone marrow mesenchymal stem cells as treatment for severe COVID-19. Stem Cells Dev. 2020, 29, 747-754. [CrossRef]

199. Medalla, M.; Chang, W.; Calderazzo, S.M.; Go, V.; Tsolias, A.; Goodliffe, J.W.; Pathak, D.; De Alba, D.; Pessina, M.; Rosene, D.L.; et al. Treatment with mesenchymal-derived extracellular vesicles reduces injury-related pathology in pyramidal neurons of monkey perilesional ventral premotor cortex. J. Neurosci. 2020, 40, 3385-3407. [CrossRef]

200. Ophelders, D.R.M.G.; Wolfs, T.G.A.M.; Jellema, R.K.; Zwanenburg, A.; Andriessen, P.; Delhaas, T.; Ludwig, A.-K.; Radtke, S.; Peter, A.; Janssen, L.; et al. Mesenchymal stromal cell-derived extracellular vesicles protect the fetal brain after hypoxia-ischemia. Stem Cells Transl. Med. 2016, 5, 754-763. [CrossRef]

201. Losurdo, M.; Pedrazzoli, M.; D’Agostino, C.; Elia, C.A.; Massenzio, F.; Lonati, E.; Mauri, M.; Rizzi, L.; Molteni, L.; Bresciani, E.; et al. Intranasal delivery of mesenchymal stem cell-derived extracellular vesicles exerts immunomodulatory and neuroprotective effects in a 3xTg model of Alzheimer's disease. Stem Cells Transl. Med. 2020, 9, 1068-1084. [CrossRef] [PubMed]

202. Perets, N.; Hertz, S.; London, M.; Offen, D. Intranasal administration of exosomes derived from mesenchymal stem cells ameliorates autistic-like behaviors of BTBR mice. Mol. Autism 2018, 9, 1-12. [CrossRef]

203. Long, Q.; Upadhya, D.; Hattiangady, B.; Kim, D.-K.; An, S.Y.; Shuai, B.; Prockop, D.J.; Shetty, A.K. Intranasal MSC-derived A1-exosomes ease inflammation, and prevent abnormal neurogenesis and memory dysfunction after status epilepticus. Proc. Natl. Acad. Sci. USA 2017, 114, E3536-E3545. [CrossRef]

204. Kalani, A.; Chaturvedi, P.; Kamat, P.K.; Maldonado, C.; Bauer, P.; Joshua, I.G.; Tyagi, S.C.; Tyagi, N. Curcumin-loaded embryonic stem cell exosomes restored neurovascular unit following ischemia-reperfusion injury. Int. J. Biochem. Cell Biol. 2016, 79, 360-369. [CrossRef] [PubMed]

205. Tan, J.L.; Lau, S.N.; Leaw, B.; Nguyen, H.P.T.; Salamonsen, L.A.; Saad, M.I.; Chan, S.T.; Zhu, D.; Krause, M.; Kim, C.; et al. Amnion epithelial cell-derived exosomes restrict lung injury and enhance endogenous lung repair. Stem Cells Transl. Med. 2018, 7, 180-196. [CrossRef] [PubMed]

206. Bhatnagar, S.; Shinagawa, K.; Castellino, F.J.; Schorey, J.S. Exosomes released from macrophages infected with intracellular pathogens stimulate a proinflammatory response in vitro and in vivo. Blood 2007, 110, 3234-3244. [CrossRef] [PubMed] 
207. Prado, N.; Marazuela, E.G.; Segura, E.; Fernández-García, H.; Villalba, M.; Théry, C.; Rodríguez, R.; Batanero, E. Exosomes from bronchoalveolar fluid of tolerized mice prevent allergic reaction. J. Immunol. 2008, 181, 1519-1525. [CrossRef] [PubMed]

208. Ezquer, F.; Quintanilla, M.E.; Morales, P.; Santapau, D.; Ezquer, M.; Kogan, M.J.; Salas-Huenuleo, E.; Herrera-Marschitz, M.; Israel, Y. Intranasal delivery of mesenchymal stem cell-derived exosomes reduces oxidative stress and markedly inhibits ethanol consumption and post-deprivation relapse drinking. Addict. Biol. 2018, 24, 994-1007. [CrossRef] [PubMed]

209. Morishita, M.; Takahashi, Y.; Nishikawa, M.; Sano, K.; Kato, K.; Yamashita, T.; Imai, T.; Saji, H.; Takakura, Y. Quantitative analysis of tissue distribution of the B16BL6-derived exosomes using a streptavidin-lactadherin fusion protein and iodine-125-labeled biotin derivative after intravenous injection in mice. J. Pharm. Sci. 2015, 104, 705-713. [CrossRef]

210. Wan, Z.; Zhao, L.; Lu, F.; Gao, X.; Dong, Y.; Zhao, Y.; Wei, M.; Yang, G.; Xing, C.; Liu, L. Mononuclear phagocyte system blockade improves therapeutic exosome delivery to the myocardium. Theranostics 2020, 10, 218-230. [CrossRef]

211. Qiu, X.; Li, Z.; Han, X.; Zhen, L.; Luo, C.; Liu, M.; Yu, K.; Ren, Y. Tumor-derived nanovesicles promote lung distribution of the therapeutic nanovector through repression of Kupffer cell-mediated phagocytosis. Theranostics 2019, 9, 2618-2636. [CrossRef]

212. Kamerkar, S.; LeBleu, V.S.; Sugimoto, H.; Yang, S.; Ruivo, C.F.; Melo, S.A.; Lee, J.J.; Kalluri, R. Exosomes facilitate therapeutic targeting of oncogenic KRAS in pancreatic cancer. Nat. Cell Biol. 2017, 546, 498-503. [CrossRef]

213. Emam, S.E.; Abu Lila, A.S.; Elsadek, N.E.; Ando, H.; Shimizu, T.; Okuhira, K.; Ishima, Y.; Mahdy, M.A.; Ghazy, F.-E.S.; Ishida, T.; et al. Cancer cell-type tropism is one of crucial determinants for the efficient systemic delivery of cancer cell-derived exosomes to tumor tissues. Eur. J. Pharm. Biopharm. 2019, 145, $27-34$. [CrossRef]

214. Kooijmans, S.; Fliervoet, L.; Van Der Meel, R.; Fens, M.; Heijnen, H.; Henegouwen, P.V.B.E.; Vader, P.; Schiffelers, R. PEGylated and targeted extracellular vesicles display enhanced cell specificity and circulation time. J. Control. Release 2016, 224, 77-85. [CrossRef]

215. Antes, T.J.; Middleton, R.C.; Luther, K.M.; Ijichi, T.; Peck, K.A.; Liu, W.J.; Valle, J.; Echavez, A.K.; Marbán, E. Targeting extracellular vesicles to injured tissue using membrane cloaking and surface display. J. Nanobiotechnol. 2018, 16, 1-15. [CrossRef]

216. Zhuang, M.; Du, D.; Pu, L.; Song, H.; Deng, M.; Long, Q.; Yin, X.; Wang, Y.; Rao, L. SPION-decorated exosome delivered BAY55-9837 targeting the pancreas through magnetism to improve the blood GLC response. Small 2019, 15, e1903135. [CrossRef]

217. Tian, T.; Zhang, H.-X.; He, C.-P.; Fan, S.; Zhu, Y.-L.; Qi, C.; Huang, N.-P.; Xiao, Z.-D.; Lu, Z.-H.; Tannous, B.A.; et al. Surface functionalized exosomes as targeted drug delivery vehicles for cerebral ischemia therapy. Biomaterials 2018, 150, 137-149. [CrossRef]

218. Khongkow, M.; Yata, T.; Boonrungsiman, S.; Ruktanonchai, U.R.; Graham, D.; Namdee, K. Surface modification of gold nanoparticles with neuron-targeted exosome for enhanced blood-brain barrier penetration. Sci. Rep. 2019, 9, 1-9. [CrossRef]

219. Liu, Y.; Li, D.; Liu, Z.; Zhou, Y.; Chu, D.; Li, X.; Jiang, X.; Hou, D.; Chen, X.; Chen, Y.; et al. Targeted exosome-mediated delivery of opioid receptor Mu siRNA for the treatment of morphine relapse. Sci. Rep. 2015, 5, 17543. [CrossRef]

220. Cui, G.-H.; Guo, H.-D.; Li, H.; Zhai, Y.; Gong, Z.-B.; Wu, J.; Liu, J.-S.; Dong, Y.-R.; Hou, S.-X. RVG-modified exosomes derived from mesenchymal stem cells rescue memory deficits by regulating inflammatory responses in a mouse model of Alzheimer's disease. Immun. Ageing 2019, 16, 10. [CrossRef]

221. Kim, H.; Yun, N.; Mun, D.; Kang, J.-Y.; Lee, S.-H.; Park, H.; Park, H.; Joung, B. Cardiac-specific delivery by cardiac tissue-targeting peptide-expressing exosomes. Biochem. Biophys. Res. Commun. 2018, 499, 803-808. [CrossRef]

222. Li, S.; Wu, Y.; Ding, F.; Yang, J.; Li, J.; Gao, X.; Zhang, C.; Feng, J. Engineering macrophage-derived exosomes for targeted chemotherapy of triple-negative breast cancer. Nanoscale 2020, 12, 10854-10862. [CrossRef]

223. Purushothaman, A.; Bandari, S.K.; Liu, J.; Mobley, J.A.; Brown, E.E.; Sanderson, R.D. Fibronectin on the surface of myeloma cell-derived exosomes mediates exosome-cell interactions. J. Biol. Chem. 2015, 291, 1652-1663. [CrossRef] 
224. Wang, J.-H.; Forterre, A.V.; Zhao, J.; Frimannsson, D.O.; Delcayre, A.; Antes, T.J.; Efron, B.; Jeffrey, S.S.; Pegram, M.D.; Matin, A. Anti-HER2 scFv-directed extracellular vesicle-mediated mRNA-based gene delivery inhibits growth of HER2-positive human breast tumor xenografts by prodrug activation. Mol. Cancer Ther. 2018, 17, 1133-1142. [CrossRef]

225. Royo, F.; Cossío, U.; De Angulo, A.R.; Llop, J.; Falcón-Pérez, J.M. Modification of the glycosylation of extracellular vesicles alters their biodistribution in mice. Nanoscale 2019, 11, 1531-1537. [CrossRef] [PubMed]

226. Tamura, R.; Uemoto, S.; Tabata, Y. Augmented liver targeting of exosomes by surface modification with cationized pullulan. Acta Biomater. 2017, 57, 274-284. [CrossRef]

227. Li, D.; Yao, S.; Zhou, Z.; Shi, J.; Huang, Z.; Wu, Z. Hyaluronan decoration of milk exosomes directs tumor-specific delivery of doxorubicin. Carbohydr. Res. 2020, 493, 108032. [CrossRef]

228. Choi, E.S.; Song, J.; Kang, Y.Y.; Mok, H. Mannose-modified serum exosomes for the elevated uptake to murine dendritic cells and lymphatic accumulation. Macromol. Biosci. 2019, 19, e1900042. [CrossRef]

229. Wiest, E.F.; Zubair, A.C. Challenges of manufacturing mesenchymal stromal cell-derived extracellular vesicles in regenerative medicine. Cytotherapy 2020, S1465-S3249. [CrossRef]

230. Lener, T.; Gimona, M.; Aigner, L.; Börger, V.; Buzas, E.; Camussi, G.; Chaput, N.; Chatterjee, D.; Court, F.A.; Del Portillo, H.A.; et al. Applying extracellular vesicles based therapeutics in clinical trials-An ISEV position paper. J. Extracell. Vesicles 2015, 4, 30087. [CrossRef]

231. Gimona, M.; Pachler, K.; Laner-Plamberger, S.; Schallmoser, K.; Rohde, E. Manufacturing of human extracellular vesicle-based therapeutics for clinical use. Int. J. Mol. Sci. 2017, 18, 1190. [CrossRef] [PubMed]

232. Mendt, M.; Kamerkar, S.; Sugimoto, H.; McAndrews, K.M.; Wu, C.-C.; Gagea, M.; Yang, S.; Blanko, E.V.R.; Peng, Q.; Ma, X.; et al. Generation and testing of clinical-grade exosomes for pancreatic cancer. JCI Insight 2018, 3, 99263. [CrossRef] [PubMed]

233. Pachler, K.; Lener, T.; Streif, D.; Dunai, Z.A.; Desgeorges, A.; Feichtner, M.; Öller, M.; Schallmoser, K.; Rohde, E.; Gimona, M. A Good Manufacturing Practice-grade standard protocol for exclusively human mesenchymal stromal cell-derived extracellular vesicles. Cytotherapy 2017, 19, 458-472. [CrossRef]

234. Watson, D.C.; Yung, B.C.; Bergamaschi, C.; Chowdhury, B.; Bear, J.; Stellas, D.; Morales-Kastresana, A.; Jones, J.C.; Felber, B.K.; Chen, X.; et al. Scalable, cGMP-compatible purification of extracellular vesicles carrying bioactive human heterodimeric IL-15/lactadherin complexes. J. Extracell. Vesicles 2018, 7, 1442088. [CrossRef] [PubMed]

235. Busatto, S.; Vilanilam, G.; Ticer, T.; Lin, W.-L.; Dickson, D.W.; Shapiro, S.; Bergese, P.; Wolfram, J. Tangential flow filtration for highly efficient concentration of extracellular vesicles from large volumes of fluid. Cells 2018, 7, 273. [CrossRef] [PubMed]

236. Bari, E.; Perteghella, S.; Catenacci, L.; Sorlini, M.; Croce, S.; Mantelli, M.; A Avanzini, M.; Sorrenti, M.; Torre, M.L. Freeze-dried and GMP-compliant pharmaceuticals containing exosomes for acellular mesenchymal stromal cell immunomodulant therapy. Nanomedicine 2019, 14, 753-765. [CrossRef]

237. Bari, E.; Perteghella, S.; Di Silvestre, D.; Sorlini, M.; Catenacci, L.; Tripodo, G.; Marrubini, G.; Rossi, R.; Tripodo, G.; Mauri, G.; et al. Pilot production of mesenchymal stem/stromal freeze-dried secretome for cell-free regenerative nanomedicine: A validated GMP-compliant process. Cells 2018, 7, 190. [CrossRef]

238. Andriolo, G.; Provasi, E.; Cicero, V.L.; Brambilla, A.; Soncin, S.; Torre, T.; Milano, G.; Biemmi, V.; Vassalli, G.; Turchetto, L.; et al. Exosomes from human cardiac progenitor cells for therapeutic applications: Development of a GMP-grade manufacturing method. Front. Physiol. 2018, 9, 1169. [CrossRef]

239. Lee, J.H.; Ha, D.H.; Go, H.-K.; Youn, J.; Kim, H.-K.; Jin, R.C.; Miller, R.B.; Kim, D.-H.; Cho, B.S.; Yi, Y.W. Reproducible large-scale isolation of exosomes from adipose tissue-derived mesenchymal stem/stromal cells and their application in acute kidney injury. Int. J. Mol. Sci. 2020, 21, 4774. [CrossRef]

240. ClinicalTrials.gov. Available online: https://clinicaltrials.gov (accessed on 30 July 2020).

Publisher's Note: MDPI stays neutral with regard to jurisdictional claims in published maps and institutional affiliations. 